\title{
A GIS-based flood risk mapping of Assam, India, using the MCDA-AHP approach at the regional and administrative level
}

\section{Laxmi Gupta}

Shiv Nadar University

Jagabandhu Dixit ( $\nabla$ jagabandhu.dixit@snu.edu.in )

Shiv Nadar University

\section{Research Article}

Keywords: Flood hazard, vulnerability, risk, GIS, analytical hierarchy process (AHP), multicriteria decision analysis (MCDA), Assam

Posted Date: October 25th, 2021

DOI: https://doi.org/10.21203/rs.3.rs-1015728/v1

License: (c) (i) This work is licensed under a Creative Commons Attribution 4.0 International License.

Read Full License

Version of Record: A version of this preprint was published at Geocarto International on March 30th, 2022. See the published version at https://doi.org/10.1080/10106049.2022.2060329. 
1 A GIS-based flood risk mapping of Assam, India, using the MCDA-AHP

2 approach at the regional and administrative level

3 Laxmi Gupta, Jagabandhu Dixit*

4 Disaster Management Laboratory, Shiv Nadar University, Delhi NCR, Greater Noida, Uttar

$5 \quad$ Pradesh 201314, India

6 E-mail address of authors: lg100@snu.edu.in; jagabandhu.dixit@snu.edu.in

7 *Corresponding Author: Jagabandhu Dixit, Email: jagabandhu.dixit@snu.edu.in

8

\begin{abstract}
9 Floods are hydrological disasters that can alter the physical, socioeconomic, and environmental
Abstract settings of a region. The objective of the present study is to develop an efficient and reliable methodology to prepare a flood risk map for Assam, the North-eastern region (NER) of India, by the integration of hazard and vulnerability components. Three indices, namely flood hazard index (FHI), flood vulnerability index (FVI), and flood risk index (FRI), are developed using multi-criteria decision analysis (MCDA) - Analytical hierarchy process (AHP) approach in GIS environment for the regional and administrative level of Assam. The selected hazard and vulnerability indicators define the topographical, geological, meteorological, drainage characteristics, land use land cover, and demographical features of Assam. The results show that more than $70 \%$ of the total area lies in the moderate to very high FHI class, $57.37 \%$ have moderate to high FVI, and more than 50\% have moderate to very high FRI class.
\end{abstract}

Keywords: Flood hazard, vulnerability, risk, GIS, analytical hierarchy process (AHP), multicriteria decision analysis (MCDA), Assam.

\section{Introduction}

Natural disasters are caused by geological, hydrological, and meteorological events resulting in immeasurable loss of lives and property and natural landscape damage. Flood is the most 
25 frequent and expensive hydro-meteorological hazard due to its high intensity of damage

26 (Tabarestani and Afzalimehr 2021). Over the past few decades, the frequency of flood and its

extent of destruction have increased significantly due to uneven distribution of rainfall, rapid snow melting, overflow of rivers, deforestation, uncontrolled urbanization, and unplanned human settlement along the coastal areas and riverbanks (Armenakis et al. 2017). From 2000 to 2019 , floods contributed $44 \%$ of the total disaster worldwide, and Asia alone experiences $41 \%$ of the total flood events of the world, affecting approximately 1.5 billion people (CRED 2020). The intensity of flood varies temporally and spatially, and its occurrence and negative consequences cannot be prevented altogether (Dewan et al. 2006). As developing countries are more vulnerable to floods, there is an urgent need to assess and manage future flood events to minimize the adverse impact. Flood management at the regional or local scale begins with identifying vulnerable areas, detailed understanding of interaction and relationships among the social, economic, and environmental factors to provide the rescue and mitigation response in case of emergency. A comprehensive flood risk map is a critical tool for executing an effective flood management system (Chakrabortty et al. 2021).

Many studies have been conducted on flood assessment at the regional, national, and global levels using different approaches and methodologies (Chen et al. 2015; Kumar 2016; Majumder et al. 2019; Sharma et al. 2019; Toosi et al. 2019). The studies have inherent challenges and limitations in identifying and quantifying hazard and vulnerability indicators, dealing with uncertainties, assigning a proper weightage of indicators, and validating the result (Sharma et al. 2018; Arora et al. 2021). The indicators involved in the risk assessment are complex and contain temporal and spatial uncertainties (Choubin et al. 2019). The main challenge is acquiring and collecting data of the selected indicators (Mishra and Sinha 2020). Over the past few decades, remote sensing has played a crucial role in monitoring floods, and it has also solved the challenges related to the availability of data (Sharma et al. 2018; Wang 
and Xie 2018; Rong et al. 2020). In recent times, GIS has been widely used in vulnerability and risk assessment studies as a decision support system for its database and analytical ability (Lyu et al. 2018; Choubin et al. 2019; Danso et al. 2020).

53 Armenakis et al. (2017) developed a flood risk map for the Don River watershed, Toronto, using high spatial resolution data and incorporated demographic indicators to enhance mitigation and preparedness planning. Dandapat and Panda (2017) delineated the flood risk zone of Paschim Medinipur in West Bengal, India, and developed a composite vulnerability index, comprising of i) Physical Vulnerability Index, ii) Social Vulnerability Index, and iii) Coping Capacity Index within the GIS framework and estimated that $24.25 \%$ of the total population of the study area is located in high to very high flood risk zones. Sharma et al. (2018), using multicriteria analysis (MCA) and geospatial technique, carried out a flood risk assessment for Kopili River Basin (KRB) in Assam, India, and estimated that a significant portion of the crop and village land falls under high and moderate flood risk zones respectively. Arora et al. (2019) applied Shannon's entropy (SE) and frequency ratio (FR) models to build a flood susceptibility model for Middle Ganga Plain using the 2008 Landsat 5TM image. Khosravi et al. (2020) developed a national scale flood susceptibility map for Iran using a deep learning convolutional neural networks $(\mathrm{CNN})$ algorithm and illustrate the importance of watershed management and prevention of uncontrolled urban expansion to control flood. Zhang et al. (2020) developed a GIS-based model for flood risk assessment at a large basin scale, such as the Yangtze River Basin, China, taking economic, social, and ecological indicators of flood risk.

Several researchers have done GIS-based flood vulnerability studies using multiple approaches (Hazarika et al. 2018; Brito et al. 2019; Dekongmen et al. 2021). Rashetnia and Jahanbani (2021) developed a GIS- fuzzy rule-based flood vulnerability index for Moreland city, 
75 (2017) carried out a flood vulnerability assessment of the western coastal cities of Mazandaran

76 Province, Iran, by classifying effective criteria into three indices, i.e., socio-economic, 77 population-environmental, and technical. Sarkar and Mondal (2020) performed a GIS-based 78 flood vulnerability classification of the Kulik river basin using the frequency ratio (FR) model.

79 Detailed flood risk assessment has been carried out by incorporating hazard and vulnerability assessment and hydrological models (Vojtek and Vojteková 2019; Sharma et al. 2018; Pathak et al. 2020). The essential factor in flood risk assessment is the proper weightage assignment to the selected indicators. Many studies have applied Multi-Criteria Decision Analysis (MCDA) to identify, integrate, or rate the flood risk assessment factors (Chen et al. 2015; Arabameri et al. 2019; Toosi et al. 2019; Mishra and Sinha 2020). Chakraborty and Mukhopadhyay (2019) integrated AHP and GIS for the development of flood risk map for Coochbehar district, West Bengal, India, by the quantification of flood risk index (FRI) using flood hazard index (FHI) and flood vulnerability index (FVI). Hazarika et al. (2018) explained that the application of multicriteria analysis in the GIS environment provides flexibility in selecting significant indicators for the flood risk assessment for Dhemaji district in the Upper Brahmaputra River valley Assam, India.

India is considered the second most flood-affected country globally, following China, and it experiences about 17 flood events per year on average, affecting approximately 345 million people (CRED 2020). The vast river network system and the world's most prominent monsoon system make about 5.74 million hectares of the total land area inundated by floods (Subrahmanyam 1988; Dhar and Nandargi 2004). The issue of flood risk is quite prominent in the Assam region of India due to the highly braided Brahmaputra River. It is mainly influenced by the southwest tropical monsoon, making the river experiencing high water levels and strong flows in the pre-monsoon season. Apart from topographic and meteorological factors, other factors like population settlement along the flood plains, erosion, and siltation of the banks 
accelerate the flood problem in the Brahmaputra basin. Every year the region suffers enormous losses and damage in terms of property and lives, so there is an urgent need to conduct a comprehensive food risk assessment and identify vulnerable areas and triggering factors.

The flood-related study for the Assam region is limited only to one aspect like hazard, vulnerability, or risk focussing only on a small area, river basin, or district level with a limited number of indicators (Borah et al. 2018; Hazarika et al. 2018; Sharma et al. 2018; Majumder et al. 2019; Pathan and Sil 2020; Sarmah et al. 2020; Pareta 2021). Considering hazard and vulnerability aspects, comprehensive flood risk assessment studies for the entire Assam region are limited. In the present study, a GIS-based comprehensive flood risk assessment of the Assam region at a regional scale and administrative level is conducted by integrating spatial, hydrological, and socio-economic indicators. The weightage of each indicator is determined by the application of the MCDA technique. The final hazard and risk maps are validated by confusion matrix or error matrix, indirect methods of relative mean error (RME), and root of mean-square error (RMSE) based on historical flood events. The study framework provides an opportunity to understand the challenges associated with flood risk management and to implement effective and sustainable flood mitigation measures and policies for urban and rural areas located at flood risk zones.

The main objectives of the present study are as follows i) to develop a GIS-based flood hazard, vulnerability, and risk index by the selection of suitable hazard and vulnerability indicators, weighted according to their significance, ii) to produce high-resolution flood risk, hazard, and vulnerability maps by integrating MCDA and GIS to identify flood-prone areas, iii) to analyze the flood risk scenario at the administrative level.

\section{Study area}

Assam lies in the north-eastern region (NER) of India, covering an area of approximately $78,438 \mathrm{~km}^{2}$, extending from $24^{\circ} 8^{\prime} \mathrm{N}$ to $28^{\circ} 2^{\prime} \mathrm{N}$ latitude and $89^{\circ} 42^{\prime} \mathrm{E}$ to $96^{\circ} \mathrm{E}$ longitude. The 
elevation of the Assam region ranges from 5-1964 m. The neighbouring states of Assam are West Bengal, Arunachal Pradesh, Nagaland, Manipur, Mizoram, Tripura, and Meghalaya. Assam shares its boundary with neighboring countries, Bhutan in the north and Bangladesh in the south (Figure 1). The Guwahati city of Assam, the largest metropolis in NER, is known as the "Gateway to Northeast India" and connects the entire NER with the rest of India. The geographical feature of Assam contains three major physiographic divisions of India i) the northern Himalayas as Eastern hills, ii) Northern plains as Brahmaputra plain, and iii) Deccan plateau as Karbi Anglong (Dikshit and Dikshit 2014).

The state of Assam can be divided into five administrative levels as (i) Upper Assam, (ii) Lower Assam, (iii) Central Assam, (iv) North Assam, and (v) Barak Valley (Figure 1). According to the 2011 census, the population growth rate is $16.93 \%$, and districts like Sonitpur, Cachar, Dhubri, Barpeta, Kamprup, Darrang, and Nagaon have high population density (Census 2011). The highest contribution to the economy of Assam is agricultural activities, and the majority of the population is rural involved in the agricultural sector (Figure 1). The climate of Assam is a tropical monsoon rainforest climate with heavy rainfall and high humidity. The summers are warm (temperature $32^{\circ}-38^{\circ}$ ) and mild winters (temperature $8^{\circ}-20^{\circ}$ ). The region experiences heavy annual rain ranging from 1500 to $3750 \mathrm{~mm}$ both in the plain and mountain areas due to the southwest monsoon, mainly in May to September, which causes floods (Chaliha et al. 2012).

\section{Figure 1}

Two river systems, Brahmaputra and Barak, are present in the Assam region. In Assam, the Brahmaputra valley is bounded by Himalayan mountains, Patkai hill ranges, and plains of Bangladesh in the northern, eastern, and southern parts, respectively (Deka et al. 2012). Due to the high flood frequency of the Brahmaputra river, it is known as "the river of sorrow" in Assam (Dhar and Nandargi 2004). The tributaries of Brahmaputra River are rainfed in nature 
and classified as north bank tributaries namely Subansiri, Ronganadi, Dikrong, Buroi,

151 Borgong, Jiabharali, Dhansiri (North) Puthimari, Manas, Beki, Aie, Sonkosh and south bank 152 tributaries namely Noadehing, Buridehing, Desang, Dikhow, Bhogdoi, Dhansiri (South), 153 Kopilli, Kulsi, Krishnai, Dhudhnoi, Jinjiran (Jain et al. 2007).

154 The Barak River system is present in the southern part of Assam, forming Barak valley, and it 155 finally drains into Bangladesh (Deka et al. 2012). The main tributaries of Barak rivers are 156 Katakhal, Jiri, Chiri, Modhura, Longai, Sonai, Rukni, and Singla, mainly rainfed tributaries 157 and are highly vulnerable to flooding during rainfall periods (Jain et al. 2007).

158 Assam experiences flood every year, causing inundation of villages, damages to croplands, loss 159 of livelihood, lakhs of families becoming homeless and affecting the entire NER due to connectivity disruption (Sharma et al. 2018). According to Rashtriya Barh Ayog (RBA), the total flood-prone area of Assam is 31.05 Lakh Hectares which constitute about $40 \%$ of the total area of Assam and $9.40 \%$ of the total flood-prone area of India. Hence, flood risk mapping is essential for Assam to facilitate effective flood management practice and planning.

\section{3. Methodology}

165 The methodology can be divided into the following sections: (1) preparation of spatial geodatabase for flood hazard and vulnerability indicator, (2) application of MCDA-AHP for weightage assignment of the indicators, (3) quantification of flood hazard index (FHI), flood vulnerability index (FVI), and flood risk index (FRI) at the regional and administrative level and (4) validation of flood hazard and risk models.

\subsection{Flood hazard indicators}

171 Flood hazard indicators are selected based on literature review, and corresponding thematic layers are generated using GIS. 
174 The criteria of elevation and surface slope can delineate the regions having different levels of

175 flood hazard. The downstream areas at lower elevation and flat slopes are more prone to

176 flooding than those with high elevation and steep slopes. The elevation and slope layers are

177 created from SRTM 1 arc-second (30m resolution) DEM. The void data was filled, mosaiced,

178 and extracted by mask with the help of spatial analyst tool, and the attributes were calculated 179 using a zonal statistics tool (Souissi et al. 2020).

\subsubsection{Drainage density}

181 Drainage density can be defined as the length of river channels per unit area of the basin, and 182 it represents flow accumulation pathways (Arora et al. 2019). The drainage network map of the study area is generated from DEM data using the hydrology tools, and drainage density is calculated by the line density tool in GIS (Vignesh et al. 2021).

\subsubsection{Distance to river}

186 Proximity to the river channels plays a critical role in flood hazard modeling. During the river's overflow, the river's volume will exceed its drainage capacity, and the water depth in the areas located near the riverbed will increase significantly. The flood inundation will not impact only the nearest river location, but the waterlogging and risk of flood will expand to the surroundings (Chakraborty and Mukhopadhyay 2019). A raster layer is created using the Euclidean distance tool in GIS (Toosi et al. 2019).

\subsubsection{Distance to embankment breach locations}

193 Embankments are man-made structures used as flood mitigation measures to protect the settlements around the riverbanks. Breaching of the embankment can cause potential flood damage (Hazarika et al. 2018). The locations of embankment breaches are identified by the historical flood records, literature review, and Assam State Disaster Management Authority 
(ASDMA) reports. The coordinates of the locations are extracted from Google Earth and using the Euclidean distance tool, a raster layer is prepared (Chakraborty and Mukhopadhyay 2019).

\subsubsection{Soil texture}

200

Soil texture is a significant flood hazard indicator as the regional internal drainage system, surface runoff, and moisture contents are highly influenced by the prevailing soil texture (Arora et al. 2018). The soil data is obtained from the Food and Agriculture Organization of the United Nations Educational, Scientific and Cultural Organization (FAO-UNESCO) and classified into five soil classes (a) sandy clay loam, (b) loam, (c) clay loam, (d) clay, and (e) sandy loam (Pareta 2021).

\subsubsection{Geology}

Geology controls the hydraulic properties of the bedrock of a region. The bedrock with fractured, high porosity and permeability enhances the infiltration rate of rainwater, thus minimizing the risk of flood. The geology map is extracted from the National Geologic Map Database (NGMDB), USGS, and classified into four classes as (a) sedimentary, (b) metamorphic, (c) Precambrian, and (d) Paleozoic rocks (Bhandari et al. 1973).

\subsubsection{Geomorphology}

213 Floods give rise to different landforms like erosional and depositional landforms. The 214 geomorphological data is obtained from the Bhukosh-Geological Survey of India (GSI) 215 (https://bhukosh.gsi.gov.in/Bhukosh/MapViewer.aspx), and classified into (a) structural hills, (b) denudational hills, (c) alluvial plains, (d) pediplain, and (e) floodplain (Vignesh et al. 2021).

\subsubsection{Topographic Wetness Index (TWI)}

TWI is used to assess the effect of topography on the hydrological process of a watershed and allows delineation of flood inundated areas (Pourali et al. 2016). For TWI, slope and flow 

by Beven and Kirkby (1979)

222

$$
T W I=\ln \left(\frac{A}{\tan \beta}\right)
$$

223 where $A$ represents source contributing area and $\tan \beta$ is ground surface slope. Higher TWI 224 indicates the area is more prone to flood, and lower value denotes the steepest slope and less 225 flood-prone regions (Arora et al. 2019).

\subsubsection{Rainfall Erosivity Factor (REF)}

228 Soil erosion is a significant problem during floods, and its rate depends on rainfall intensity.

229 With the help of REF, the impact of rainfall intensity on soil erosion can be quantified. REF is 230 calculated by equation (2) developed by Singh et al. (1981) using the average daily rainfall data 231 of 21 years from 2000 to 2020 (Pathan and Sil 2020).

$$
R=79+0.363 \times P
$$

233 Here, $R$ and $P$ represent rainfall erosivity factors ( $\mathrm{MJ} \mathrm{mm} \mathrm{ha}^{-1} \mathrm{hr}^{-1}$ year ${ }^{-1}$ ) and mean annual 234 precipitation $(\mathrm{mm})$, respectively.

\subsubsection{Rainfall intensity}

236 Rainfall intensity is a crucial parameter that induces the occurrence of floods. Rainfall data 237 from 2000 to 2020 are collected from Indian Meteorological Department (IMD), and rainfall 238 intensity is determined for 114 grid points using equation (3). Rainfall intensity map is developed using Modified Fournier Index (MFI) approach and interpolated by Inverse Distance

240 Weighting (IDW) interpolation in GIS (Toosi et al. 2019). 


$$
M F I=\sum_{i=1}^{12} \frac{P_{i}^{2}}{P}
$$

$242 \quad P_{i}$ and $P$ are the mean monthly and annual precipitation $(\mathrm{mm})$, respectively.

244 In the present study, rainfall-runoff modeling is performed using the National Resources 245 Conservation Services-Curve Number (NRCS-CN) method to estimate the surface runoff 246 coefficient for 33 basins in the study area (Pathak et al. 2020). The required input datasets are 247 DEM, soil data, land use land cover (LULC), and rainfall data of the study area (Toosi et al. 248 2019).

249 The runoff coefficient $(R C)$ is calculated by the rational method using equation (4)

250

$$
R C=\frac{Q}{P}
$$

251 The surface runoff of an area is given by equations (5) to (10)

$$
P=I+F+Q
$$

$253 P, F$, and $Q$ signify precipitation, initial abstraction, actual retention, and direct runoff, 254 respectively.

255 The ratio of actual rainfall retention to the potential maximum retention $S$ is equal to the ratio 256 of direct runoff to rainfall minus initial abstraction.

$$
\begin{aligned}
& \frac{(P-I-Q)}{S}=\frac{Q}{(P-I)} \\
& Q=\frac{(P-I)^{2}}{(P-I+S)}
\end{aligned}
$$

$$
I=\lambda S
$$




$$
Q=\frac{(P-\lambda S)^{2}}{P+(1-\lambda) S} \quad \text { For } P>\lambda S
$$

$$
\mathrm{Q}=0 \quad \text { For } P \leq \lambda S
$$

$263 \lambda$ is initial abstraction coefficient (ranging from 0 to infinity); in general, $\lambda=0.2$ is 264 recommended.

265 The value of $S$ for the derived curve number $(C N)$ of the basin can be calculated by equation 266 (11).

$$
S=\frac{25400}{C N}-254
$$

$268 C N$ is a dimensionless parameter ranging between 0 to 100 (USAD 2004; Al-Ghobari et al. $2692020)$.

$270 C N_{i}$ values are determined for each sub-basin, with different land uses, soil types, and areas $271\left(A_{i}\right)$. The final composite curve number $\left(C N_{w}\right)$ is estimated by weighting the resulting $\mathrm{CN}$ 272 values in equation (12).

$$
C N_{w}=\frac{C N_{i} \times A_{i}}{A}
$$

\subsection{Flood Vulnerability indicators}

275 Datasets for flood vulnerability indicators were collected from different global, national, 276 regional platforms and processed in the GIS environment for further analysis.

\section{3.2.1. Population density}

278 Population density data are obtained from the Census 2011 (Census 2011). It directly relates to vulnerability because more people will be exposed to hazardous events in an area with a high

280 population density (Chakraborty and Mukhopadhyay 2019).

\subsubsection{Vulnerable population}

282 The vulnerable population of the study area comprises females, children, and the old-aged population due to their low resilient capacity and high dependency. From the Census 2011, the 
data are extracted to estimate the spatial distribution of the vulnerable population (Sharma et al. 2018).

\subsubsection{Employment rate}

287 The economic status of the population highly influences the coping capacity of an area. A well288 defined income source of a community improves the living standard and increases the community's coping capacity. The employment status for the Assam region is acquired from Census 2011 (Agrawal et al. 2021).

\subsubsection{Literacy rate}

292 The literacy rate of an area is directly related to a community's awareness about the hazard and 293 helps in the preparedness during the hazardous event. Here, the literacy rate of Assam is obtained from Census 2011, and its thematic layer is generated (Sharma et al. 2018).

\subsubsection{Household with more than four family members}

The household size directly influences the vulnerability component. A smaller household will be less vulnerable than a household with more family members. The data of households are collected from Census 2011 (Agrawal et al. 2021).

\subsubsection{Dilapidated house}

The condition of building structures determines their coping capacity towards any disaster. If the building, mainly a residential building, is dilapidated, its vulnerability will increase. From the Census 2011, data regarding the dilapidated houses are obtained (Agrawal et al. 2021).

\section{Figure 3}

\section{$304 \quad$ 3.2.7. Building density}

305 Building density is considered an essential indicator for infrastructure vulnerability assessment, 306 and it is positively correlated with the vulnerability index. For the present study, building 307 density is calculated using the data obtained from the Census 2011 (Agrawal et al. 2021).

\subsubsection{Distance to roads}


309 A well-connected and maintained transportation system is one of the essential infrastructure 310 components of a region. Road connectivity plays a critical role in relief and rescue operations

311 during an emergency. Those settlements nearer to the roads are less vulnerable as they can be 312 evacuated or rescued faster than the population residing in the remote areas (Hazarika et al. 313 2018). With the help of OpenStreetMap, major and minor roads are extracted and digitized in 314 GIS. A raster dataset is generated by the Euclidean distance tool in GIS (Pareta 2021).

\subsubsection{Distance to hospital}

316 Proximity to hospitals and healthcare centers will facilitate emergency rescue operations and 317 post-disaster health management activities. The locations of hospitals are obtained from the 318 Department of Health \& Family Welfare, Government of Assam. Coordinates of 624 government hospitals are extracted from Google Earth, and distance from hospitals is calculated using the Euclidean distance tool in GIS (Chakraborty and Mukhopadhyay 2019;

321 Toosi et al. 2019).

\subsubsection{Distance to stream confluence}

323 The areas near the stream confluence are more prone to flood inundation because during the 324 flood at the confluence point, the channel tends to carry combined discharge and load of two or more upstream tributaries (Chakraborty and Mukhopadhyay 2019). From the drainage network layer of the study area, confluence points are identified, and the distance from the confluence point is determined using the Euclidean distance tool in GIS (Arora et al. 2019).

\subsubsection{Flow accumulation}

329 Flow accumulation is the flow concentration, and it is directly related to flood vulnerability 330 (Vojtek and Vojteková 2019). It is lower upstream but higher downstream as many tributaries 331 join the main channel downstream. For the present study, flow accumulation raster is prepared 332 by $30 \mathrm{~m}$ resolution of DEM data using hydrology tool in GIS. 
334 LULC governs the relationship between different hydrological parameters like runoff, 335 infiltration, and rainfall abstraction (Toosi et al. 2019). The urban and pasture land increase the 336 overflow of water, whereas forest and dense natural vegetation increase water infiltration and 337 abstractions. The land use land cover map with ten LULC classes for the study area is derived 338 from Sentinel -2 imagery (10 m resolution) by ESRI (Kontgis et al. 2021). The map is further 339 reclassified into five categories (a) water, (b) built-up area, (c) agricultural land, (d) natural 340 vegetation, and (e) bare land and validated by calculating the kappa coefficient (Vignesh et al. $3412021)$.

342 The accuracy of the LULC map is checked by overall accuracy (AOVERALL) and Kappa $(K)$ 343 statistics, User's and Producer's accuracy (AUSER and $\left.A_{P R O D U C E R}\right)$ using equations (13) to (16) 344 (Gibril et al. 2017; Hishe et al. 2020). The detailed error matrix was computed for each 345 classification image, as it allowed evaluation of $A_{U S E R}$ and $A_{P R O D U C E R}$ for each of the 346 information classes included in our classification scheme (Table 1). For the present study, 347 Google Earth was used for the validation of classification with $N=373$ points.

$$
\begin{gathered}
K=\frac{N \sum_{i=1}^{r} m_{i i}-\sum_{i=1}^{r}\left(m_{i+1}\right)\left(m_{+i}\right)}{N^{2}-\sum_{i=1}^{r}\left(m_{i+}\right)\left(m_{+i}\right)} \\
A_{\text {OVERALL }}=\left(\frac{1}{N}\right) \sum_{i=1}^{\gamma} n_{i i}
\end{gathered}
$$

$$
A_{\text {PRODUCER }}=\frac{n_{i i}}{n_{\text {icolumm }}}
$$

$$
A_{U S E R}=\frac{n_{i i}}{n_{\text {irow }}}
$$


Where $r$ denotes the number of rows, $m_{i i}$ number of observations in row $i$ and column $i, m_{+i}$ and $m_{i+}$ are the marginal total of row $(r)$ and column $(i)$, respectively, $n_{i i}$ are the number of observations correctly classified.

\section{Table 1}

The value of overall accuracy and Kappa coefficient are $90.88 \%$ and 0.885 , respectively. The Kappa coefficient value close to 1 signifies that the classified image and reference image shows perfect agreement, and hence the classification performed in the study is acceptable.

All the thematic layers of flood hazard and vulnerability indicators are resampled to a $30 \mathrm{~m}$ raster layer to minimize the error (Chakraborty and Mukhopadhyay 2019). Jenks Natural Breaks method is applied to classify flood hazard and vulnerability indicators, except for distance from rivers, roads, stream confluence, hospitals, embankment breach location, LULC, geology, geomorphology, and soil type (Toosi et al. 2019).

\subsection{Analytical Hierarchy Process (AHP) as Multi-Criteria Decision Analysis (MCDA)} technique

The weightage to flood hazard and vulnerability indicators are assigned using Analytical Hierarchy Process (AHP) as Multi-Criteria Decision Analysis (MCDA) technique. It is considered a systematic, multi-objective, and reliable approach developed by Saaty (Saaty 2000, 2008). AHP decomposes a problem into a simple and subjective evaluated sub-problem hierarchy (Saaty 2000). The indicators are weighted according to relative importance on a scale from 1 to 9 (Saaty 2008). The steps of AHP are as follows:

Step 1. Decompose the complex unstructured problem into a hierarchy of goals, criteria, and indicators.

Step 2. Make a pairwise comparison of the indicators based on a qualitative scale (Table 2). 
375 Step 3. Construct a square matrix of $\mathrm{n} \times \mathrm{n}$ where diagonal elements of the matrix are 1 . If the 376 indicator in the $i^{\text {th }}$ row of the matrix is more important than the indicator in the $j^{\text {th }}$ column, then

377 the element $(i, j)$ will be assigned a value greater than 1 , and the element $(j, i)$ will be its 378 reciprocal.

\section{Table 2}

Table 3

Step 4. The weights of the pairwise comparison matrix are normalized by the eigenvector method using the equations (17) to (18).

$$
\begin{gathered}
X_{i j}=\frac{C_{i j}}{\sum_{i=1}^{n} C_{i j}} \\
V_{i j}=\frac{\sum_{j=1}^{n} X_{i j}}{n}
\end{gathered}
$$

where $C_{i j}$ is the indicator value in the pairwise comparison matrix, $X_{i j}$ is the normalized score, and $V_{i j}$ is the priority vector representing the indicators' weight ( $\left.W_{\text {ind }}\right)$.

Finally, the assigned normalized weights are tested for consistency ratio $(C R)$ using equation (19), where $C R$ must be less than 0.1 and consistency index $(C I)$ is calculated by equation (20).

$$
C R=\frac{C I}{R I}
$$

$\lambda_{\max }, R I$ (Table 3 ), and $n$ are principal eigenvector, random index, and the number of indicators, respectively.

\subsection{Flood hazard, vulnerability, and risk index}

Flood hazard index $(F H I)$, flood vulnerability index $(F V I)$, and flood risk index $(F R I)$ are calculated in GIS using a raster calculator by equations (21) to (23). The index scores are 
396

397

398

399

400

401

402

403

404

405

406

407

408

409

410

411

412

413

normalized and converted into a raster of grid size $30 \mathrm{~m} \times 30 \mathrm{~m}$ to minimize error (Chakraborty and Mukhopadhyay 2019).

$$
\begin{aligned}
& F H I=\left(W_{E L V} \times E L V\right)+\left(W_{S l} \times S l\right)+\left(W_{D d} \times D d\right)+\left(W_{D r} \times D r\right)+\left(W_{D e} \times D e\right)+\left(W_{S t} \times S t\right)+ \\
& \left(W_{G e o} \times G e o\right)+\left(W_{G m} \times G m\right)+\left(W_{T W I} \times T W I\right)+\left(W_{M F I} \times M F I\right)+\left(W_{R E F} \times R E F\right)+\left(W_{R C} \times R C\right)
\end{aligned}
$$

$$
\begin{aligned}
& F V I=\left(W_{P D} \times P D\right)+\left(W_{V P} \times V P\right)+\left(W_{E m p} \times E m p\right)+\left(W_{L R} \times L R\right)+\left(W_{H H 4} \times H H 4\right)+\left(W_{D P H} \times D P H\right)+ \\
& \left(W_{B D} \times B D\right)+\left(W_{D R d} \times D R d\right)+\left(W_{D H} \times D H\right)+\left(W_{D c} \times D c\right)+\left(W_{F A} \times F A\right)+\left(W_{L U L C} \times L U L C\right)
\end{aligned}
$$

Here, $W_{\text {indicator }}$ is the weight of respective indicators.

$$
F R I=F H I \times F V I
$$

All the indices are classified into five classes: very low, low, moderate, high, and very high.

\subsection{Flood hazard map validation}

To validate the hazard map 478 historical flood location points are selected and used for the performance analysis based on the accuracy assessment of flood classification. The confusion matrix or error matrix is suitable to validate the accuracy (Arora et al. 2019; Cabrera and Lee 2019). Several parameters like overall accuracy $(O A)$, true positive rate $\left(P R_{T R U E}\right)$, false positive rate $\left(P R_{F A L S E}\right)$, true negative rate $\left(N R_{T R U E}\right)$, and false-negative rate $\left(N R_{F A L S E}\right)$ are calculated using the equations (24) to (28):

$$
O A=\frac{P_{T R U E}+N_{T R U E}}{P+N}=\frac{P_{T R U E}+N_{T R U E}}{P_{\text {TRUE }}+N_{\text {TRUE }}+P_{F A L S E}+N_{F A L S E}}
$$

$$
P R_{\text {TRUE }}=\frac{P_{\text {TRUE }}}{P_{\text {TRUE }}+N_{\text {FALSE }}}
$$

$$
N R_{\text {TRUE }}=\frac{N_{\text {TRUE }}}{N_{\text {TRUE }}+P_{\text {FALSE }}}
$$




$$
N R_{F A L S E}=\frac{N_{\text {FALSE }}}{N_{F A L S E}+P_{\text {TRUE }}}=1-P R_{\text {TRUE }}
$$

416 where $P, N, P_{T R U E}, N_{T R U E}, P_{F A L S E}$, and $N_{F A L S E}$ denote positive, negative, true positive, true 417 negative, false positive, and false negative, respectively.

418 For the 478 points, elevations are extracted by using GIS tools. The elevation for the points 419 ranged between $5 \mathrm{~m}$ to $135 \mathrm{~m}$. The points are interpolated by the Kriging interpolation method 420 and identified that points belonging to this elevation range are flood-prone areas.

\subsection{Flood risk map validation}

422 Due to a lack of data on flood depths, storm discharge at micro levels, the validation of the 423 result was based on historical flood events and flood-prone areas reported by Disaster 424 Management authorities at state and district levels. A total of 1263 inundation-prone settlements in the study area are identified and converted as georectified points in the GIS environment. From the settlement layer, a set of points are generated for very low to very high

427 flood risk with the help of a spatial statistics tool. To validate the flood risk model (FRM), indirect methods of relative mean error $(R M E)$ and root of mean-square error (RMSE) are applied by considering observed locations $(O L)$ for reported sites and predicted locations $(P L)$

430 for modeled sites (Chakraborty and Mukhopadhyay 2019). The values of RME, RMSE, percentage of relative error $\left(R E_{i}\right)$, and standard error $\left(S E_{i}\right)$ for FRM are calculated using 432 equations (29) to (32).

$$
R M E=\frac{1}{n} \sum R E i
$$

$$
R E_{i}=\frac{(O L-P L) \times 100}{O L}
$$

$$
R M S E=\sqrt{\frac{1}{n}\left(\sum S E_{i}\right)}
$$


437

438

439

440

441

442

\section{Results and discussion}

\subsection{Spatial distribution of Flood hazard and vulnerability indicators}

The extent of flood hazard and vulnerability depends on topographical, geological, drainage characteristics, hydrological, meteorological, demographical conditions of the region (Toosi et al. 2019; Pathak et al. 2020; Hazarika et al. 2018; Arora et al. 2019). The flood hazard and vulnerability indicators are classified into different classes, and effective weights are assigned according to their significance i.e., very low (1), low (2), moderate (3), high (4), and very high (5) (Table 4 and 5) (Chakraborty and Mukhopadhyay 2019; Pathak et al. 2020).

A thematic layer of flood hazard indicators is generated in GIS (Figure 2(a)-2(1)). Lower, North, Upper, and Barak valley of Assam are more flood-prone due to lower elevation, milder slopes, lower TWI, sedimentary rock structure, and sandy clay loam soil texture. The drainage density is relatively low in Northern Assam and high in the Lower, Upper, Central, and Barak valleys of Assam, increasing its flood susceptibility (Vignesh et al. 2021). The Lower, Northern and Upper Assam are highly susceptible to flood due to alluvial and flood plains. The REF values in the Upper and Lower Assam ranges from very low to very high, very high to moderate in the Barak valley, very low to low in Central, and moderate to very low in Northern Assam. The rainfall intensity and runoff coefficient are moderate to very high for the Lower and Barak valley of Assam.

\section{Table 4}

The vulnerability indicators can be grouped into four types of vulnerability (i) socioeconomic (population density, vulnerable population, employment rate, literacy rate, and household with more than 4 family members), (ii) infrastructure (building density, distance to roads, distance to hospital, and several dilapidated houses), (iii) hydrological (flow accumulation and distance 
to stream confluences) and (iv) land use (LULC) (Figure 3(a)-3(1)) (Sharma et al. 2018). The of Assam and low to very low in Central and Northern Assam.

464 The vulnerable population is very high in some parts of the Lower, Central, Upper, and Barak valley of Assam. The employment rate is very high in the upper region of Assam due to the predominance of agricultural activities, and the majority of the population is self-employed.

467 Very high to moderate literacy rates are found in the Upper, Central, and Barak valley of Assam and can be considered less vulnerable than those with low literacy rates. The housing condition of Central and Upper Assam lies in very low to low vulnerable class along with moderate to high building density. The LULC distribution is classified according to the flood hazard, vulnerability, and risk index for the Assam region (Figure 4(a)-4(d)) (Toosi et al. 2019). The indicators are dynamic and vary spatially and temporally (Souissi et al. 2020).

\section{Figure 4}

\section{4.2. Weightage assignment of indicators by AHP}

475 In the present study AHP, a multi-criteria decision analysis approach is used to generate flood hazard index (FHI) and flood vulnerability index (FVI). The consistency ratio (CR) is 0.06 and

4770.03 for flood hazard and vulnerability indicators, respectively, and the consistency index (CI) 478 is 0.09 for flood hazard and 0.04 for vulnerability indicators. Highly contributing factors for 479 flood hazard are rainfall intensity, slope, runoff coefficient, elevation, distance to rivers, 480 drainage density, and the least significant factors are erosivity factor, geomorphology, and geology (Table 6) (Toosi et al. 2019). 
483 For flood vulnerability, highly contributing factors include population density, vulnerable

484 population, land use landcover, whereas the least contributing factors are identified as

485

486

487 employment and literacy rate (Table 7) (Chakraborty and Mukhopadhyay 2019). The weightage assigned to the indicators has a critical role in flood risk modeling (Arabameri et al. 2019; Chakrabortty et al. 2021).

\section{Table 7}

\subsection{Mapping of FHI, FVI, and FRI}

From the spatial distribution of the FHI, the influence of rainfall intensity, runoff coefficient, elevation, surface slope, distance to the river, and drainage density are highly significant (Toosi et al. 2019). The resulting flood hazard map shows a substantial relationship with the controlling factors and FHI values. Areas with alluvial plains fall under very high to moderate FHI, while regions with structural and denudational hills have very low to low flood hazard zonation (Vignesh et al. 2021). Upper and lower Assam have high TWI, and it comes under very high to high flood hazard zone. The Lower, Upper, and Barak valleys of Assam have very high FHI and low to very low FHI values observed for the Central Assam (Figure 5a). More than $70 \%$ of the total area lies in the moderate to very high FHI class (Figure $5 \mathrm{~d}$ ).

In the present study, significant weightage is given to demographic, land use landcover infrastructure, and hydrological indicators as vulnerability indicators. The FVI ranges from low to very low for Central and Upper Assam, high to very high for Lower Assam, moderate to low for Northern Assam, and low to very high for the Barak valley. A large proportion of the area is in a very high vulnerable zone located along West Bengal, Meghalaya, and Indo-Bangladesh border. These areas have very high to moderate population density, a very high percentage of the vulnerable population, low literacy and employment rate, and high building density (Chakraborty and Mukhopadhyay 2019). About $57.37 \%$ of the total areas have moderate to high FVI (Figure 5d). Very high to moderate FVI are observed for Lower and Barak valley of 
Assam. For Upper and Northern Assam, moderate to very low FVI values are identified, and a large part of Central Assam shows very low flood vulnerability (Figure 5b).

511 The FHI and FVI profiles of Assam are different because flood hazards represent real and existing physical elements that alter gradually, and the more dynamic indicators determine

513 flood vulnerability (Sharma et al 2018).

514 The spatial distribution of FRI shows that both FHI and FVI contribute significantly to the 515 generation of FRI, but their influences differ in many parts of the study area. Northern Assam 516 has moderate to high FHI, and moderate to low FVI and FRI classes. For Upper Assam, the 517 FHI ranges from moderate to very high, FVI and FRI range from very low to moderate. Barak valley has moderate to very high FHI values, low to high FVI and FRI classes. Lower Assam falls in the moderate to a very high flood risk category, and Central Assam has low to very low flood risk values. The spatial distribution of FRI indicates that flood vulnerability indicators contribute more to the estimation of risk than the hazard indicators (Figure 5c). Moderate to very high FRI is observed for more than $50 \%$ of the total study area (Figure $5 \mathrm{~d}$ ).

\subsubsection{Lower Assam} In lower Assam, $90.29 \%, 86.03 \%$, and $88.32 \%$ of the total study area fall under moderate to very high FHI, FVI and FRI classes, respectively (Figure 6(p)-6(r)). Dhubri, Goalpara Barpeta,

527 Bongaigaon, and Chirang lie in high to very high FHI, FVI, and FRI zones. The FRI class for 528 Kokrajhar district ranges from high to low, with moderate FVI and very high FHI. Nalbari lies in very high to high flood hazard zonation with moderate to high FVI resulting in high to moderate FRI. The area of Kamrup and Baksa falls under very high to low FHI and FVI class and high to low FRI class. The Kamprup metropolitan has very low to low FRI due to very low FHI and moderate FVI (Figure 6(a)-6(c)). 
534 More than 55\% of the total area of Upper Assam falls under high to very high FHI class, and 535 less than $10 \%$ lies in high to very high FVI and FRI class (Figure 6(p)-6(r)). All the seven 536 Upper Assam districts are in high FHI classes but moderate to very low FVI and FRI classes. 537 (Figure 6(d)-6(f)).

\subsubsection{Northern Assam}

539 The Darrang district lies under high to very high flood hazard, vulnerability, and risk class in 540 the Northern Assam. For Sonitpur, flood risk ranges from moderate to low due to lower flood 541 hazards and vulnerability. Udalgiri district lies in a very high FVI zone but has moderate to 542 low FHI, making it moderate towards flood susceptibility (Figure 6(g)-6(i)). The very high to moderate FHI, FVI, and FRI classes contribute approximately $85 \%, 71 \%$, and $63 \%$ of the total study area, respectively (Figure 6(p)-6(r)).

\subsubsection{Central Assam}

547 The districts of Morigaon and Nagaon lie in moderate flood hazard and risk zones, having very high FVI due to high population density, low literacy rate, and agricultural lands and built-up areas. Similar variations are observed for FHI, FVI, and FRI classes for Karbi Anglong and Dima Hasao districts (Figure 6(j)-6(1)). About 70\% of the total study area falls under very low

551 flood risk and vulnerability zone (Figure 6(q)-6(r)).

553 The FVI for the Karimganj district of Barak valley is very high, with moderate to very high 554 FHI and FRI classes. On the other hand, Hailakandi and Cachar districts lie in moderate to low 555 FVI and FRI classes with very high FHI (Figure 6(m)-6(o)). More than $60 \%$ of the study area 556 is observed under moderate to very high FRI zones (Figure 6r). 
The detailed study on flood risk assessment is essential to create more comprehensive and integrated flood risk management practices for flood-prone regions like Assam. Many studies have considered MCDA to develop a flood risk model using hydrological, geological, demographical, and LULC indicators (Armenakis et al. 2017; Chakrabortty et al. 2021). The spatial distribution of the indicators has a critical impact on the variation of FHI, FVI, and FRI at the regional and administrative levels. For FRI development, the main limitations are related to the database, including soil, topography, meteorological, lithological, historical flood events, etc (Sarmah et al. 2020; Souissi et al. 2020). In the flood hazard assessment, rainfall intensity is given higher weightage, followed by slope and runoff coefficient (Toosi et al. 2019). Factors like elevation, slope, distance to river, geomorphology, soil type drainage density are used by many researchers for the flood hazard assessment of Assam and other areas (Kumar 2016; Pathak et al. 2020; Pareta 2021). But factors like TWI, REF, and runoff coefficient are limited, especially for Assam.

Similarly, for the FVI, more weightage is given to demographical indicators and LULC of the study area. The weightage assignment of the flood and vulnerability indicators is not constant, and it depends from region to region (Sarkar and Mondal 2020; Rashetnia and Jahanbani 2021).

573 The results obtained by integrating MCDA(AHP)-GIS for the flood risk assessment of Assam will provide the urban planners, engineers, policymakers a reliable and efficient tool for identifying flood-prone zones and making effective preparedness and mitigation strategies.

\section{5. Result validation}

\section{5.1. Flood hazard index map}

578 Based on 478 historical flood points, a resulting flood map was created by the interpolation method in GIS software and overlaid with the flood hazard index map, obtained by applying AHP. After performing the accuracy assessment by the confusion matrix or error matrix method, the number of pixels that matched correctly (PTRUE) and mistakenly (PFALSE) are 


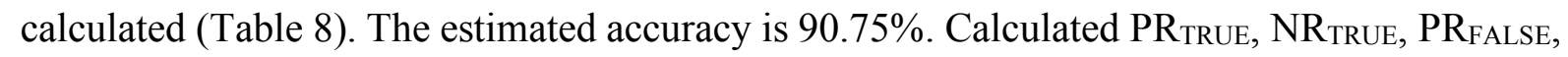
and $\mathrm{NR}_{\mathrm{FALSE}}$ values are $0.90,0.92,0.08$, and 0.10 , respectively.

\section{Table 8}

\subsection{Flood risk index map}

Relative mean error (RME) and root of mean-square error (RMSE) were applied to validate the flood risk map of Assam, based on the selection of 1263 flood-prone locations. The model accurately predicted 1089 locations and has an accuracy of $86.22 \%$, the overall efficiency of the model is found to be satisfactory, with RMSE equal to 0.105 and RME equal to 0.391 . For the districts like Barpeta, Chirang, Cachar, Lakhimpur, Nalbari, Morigaon, Tinsukia, Karimganj, Golaghat, Jorhat, Udalguri, Naogaon, Sivasagar, Dima Hasao, Dhubri, Sonitpur, Darrang, Dhemaji, Goalpara, Bongaigaon, Kokrajhar shows accuracy level between 85-96\% and district like Kamrup metropolitan, Kamrup rural, Baksa, Hailakandi, Dibrugarh, Karbi Anglong have accuracy level ranging from $78-85 \%$.

\section{Conclusion}

In the present study, the flood hazard, vulnerability, and risk maps of Assam at the regional and administrative levels are developed by combining MCDA-AHP and GIS tools. The flood hazard and vulnerability layer are created using different indicators, and AHP is applied to assigned weightage to the indicator. The final flood risk map is obtained by integrating hazard and vulnerability indices in GIS software and validated by confusion matrix, RME, and RMSE based on historical flood events. The results show that more than $70 \%$ of the total area lies in the moderate to very high FHI class, and it includes Lower, Upper, and Barak valley of Assam have very high FHI. About $57.37 \%$ of the total areas have moderate to high FVI consisting of the Lower and Barak valley of Assam, whereas the Central Assam shows very low flood vulnerability. For more than $50 \%$ of the total study area, moderate to very high FRI are observed in the Lower, Upper, and Barak valley of Assam. The FHI, FVI, and FRI indices 
estimate the flood-prone areas of Assam and spatial variation of the indicators responsible for

608 flood occurrence. The districts like Dhubri, Goalpara Barpeta, Bongaigaon, Darrang, 609 Karimganj, and Chirang lie in high to very high FHI, FVI, and FRI zones. The study has 610 inherent limitations related to the database, including soil, topography, meteorological, 611 lithological, historical flood events, and weightage assignment. The results may provide the 612 local governing authorities and stakeholders with a comprehensive tool for flood risk 613 management. The methodology can be implemented in other locations to carry out a flood risk 614 assessment with more accurate and precise data sources using time and cost-effective GIS615 based tools.

\section{Data Availability Statement}

617 The authors confirm that the data supporting the findings of this study are available within the 618 article and some of the raw data were generated at our laboratory and derived data supporting 619 the findings of this study are available upon reasonable request.

\section{Declaration of Competing Interests}

621 The authors declare that they have no known competing financial interests or non-financial interests or personal relationships that are directly or indirectly related to the work submitted for publication that could have appeared to influence the work reported in this paper.

\section{References}

625

Agrawal N, Gupta L, Dixit J. 2021. Assessment of the Socioeconomic Vulnerability to Seismic Hazards in the National Capital Region of India Using Factor Analysis. Sustainability. 13(17):9652.

Al-Ghobari H, Dewidar A, Alataway A. 2020. Estimation of surface water runoff for a semi630 arid area using RS and GIS-based SCS-CN method. Water. 12(7):1924. 
Arabameri A, Rezaei K, Cerdà A, Conoscenti C, Kalantari Z. 2019. A comparison of statistical methods and multi-criteria decision making to map flood hazard susceptibility in Northern Iran. Sci Total Environ. 660:443-458.

Armenakis C, Du EX, Natesan S, Persad RA, Zhang Y. 2017. Flood risk assessment in urban areas based on spatial analytics and social factors. Geosciences. 7(4):123.

Arora A, Pandey M, Siddiqui MA, Hong H, Mishra VN. 2019. Spatial flood susceptibility prediction in Middle Ganga Plain: comparison of frequency ratio and Shannon's entropy models. Geocarto Int. 1-32.

Beven KJ, Kirkby MJ. 1979. A physically based, variable contributing area model of basin hydrology. Hydrol Sci J. 24(1):43-69.

Bhandari LL, Fuloria RC, Sastri VV. 1973. Stratigraphy of Assam Valley, India. AAPG Bulletin. 57(4):642-654.

Borah SB, Sivasankar T, Ramya MNS, Raju PLN. 2018. Flood inundation mapping and monitoring in Kaziranga National Park, Assam using Sentinel-1 SAR data. Environ monitoring and Assess. 190(9):1-11.

Brito MMD, Evers M, Almoradie ADS. 2018. Participatory flood vulnerability assessment: a multi-criteria approach. Hydrol Earth Syst Sci. 22(1):373-390.

Cabrera JS, Lee HS. 2019. Flood-prone area assessment using GIS-based multi-criteria analysis: a case study in Davao Oriental, Philippines. Water. 11(11):2203.

Census. 2011. Population Census 2011. https://www.census2011.co.in/

Chakrabortty R, Chandra Pal S, Rezaie F, Arabameri A, Lee S, Roy P, Saha A, Chowdhuri I, Moayedi H. 2021. Flash-flood hazard susceptibility mapping in Kangsabati River Basin, India. Geocarto Int. 1-23. 
654 Chakraborty S, Mukhopadhyay S. 2019. Assessing flood risk using analytical hierarchy

655

656

657

658

659

660

661

662

663

664

665

666

667

668

669

670

671

672

673

674

675

676 process (AHP) and geographical information system (GIS): application in Coochbehar district of West Bengal, India. Nat Hazards. 99(1):247-274.

Chaliha S, Sengupta A, Sharma N, Ravindranath NH. 2012. Climate variability and farmer's vulnerability in a flood-prone district of Assam. Int J Climate Change Strategies and Manage. 4:179-200

Chen H, Ito Y, Sawamukai M, Tokunaga T. 2015. Flood hazard assessment in the Kujukuri Plain of Chiba Prefecture, Japan, based on GIS and multicriteria decision analysis. Nat Hazards. 78(1):05-120.

Choubin B, Moradi E, Golshan M, Adamowski J, Sajedi-Hosseini F, Mosavi A. 2019. An ensemble prediction of flood susceptibility using multivariate discriminant analysis, classification and regression trees, and support vector machines. Sci Total Environ. 651:2087-2096.

CRED. 2019. EM-DAT:The Int Disaster Database. Centre for Research on the Epidemiology of Disasters.

Dandapat K, Panda GK. 2017. Flood vulnerability analysis and risk assessment using analytical hierarchy process. Model Earth Syst Environ. 3(4):1627-1646.

Danso SY, Ma Y, Adjakloe YDA, Addo IY. 2020. Application of an Index-Based Approach in Geospatial Techniques for the Mapping of Flood Hazard Areas: A Case of Cape Coast Metropolis in Ghana. Water. 12(12):3483.

Deka RL, Mahanta C, Pathak H, Nath KK, Das S. 2013. Trends and fluctuations of rainfall regime in the Brahmaputra and Barak basins of Assam, India. Theoretical and Appl climatology. 114(1):61-71. 
Dekongmen BW, Kabo-bah AT, Domfeh MK, Sunkari ED, Dile YT, Antwi EO, Gyimah RAA. 2021. Flood vulnerability assessment in the Accra Metropolis, southeastern Ghana. Appl Water Sci. 11(7):1-10.

Dewan AM, Kumamoto T, Nishigaki M. 2006. Flood hazard delineation in greater Dhaka, Bangladesh using an integrated GIS and remote sensing approach. Geocarto Int. 21(2):3338.

Dhar ON, Nandargi S. 2004. Rainfall distribution over the Arunachal Pradesh Himalayas. Weather. 59(6):155-157.

Dikshit KR, Dikshit JK. 2014. Relief features of north-east India. In North-East India: Land, People and Economy. Dordrecht: Springer ; p.91-125

FAO and ITPS. 2015. Main report: Status of the World's Soil Resources; Food and Agriculture Organization of the United Nations and Intergovernmental Technical Panel on Soils, Rome, Italy.

Gibril MBA, Bakar SA, Yao K, Idrees MO, Pradhan B. 2017. Fusion of RADARSAT-2 and multispectral optical remote sensing data for LULC extraction in a tropical agricultural area. Geocarto Int. 32(7):735-748.

Hazarika N, Barman D, Das AK, Sarma AK, Borah SB. 2018. Assessing and mapping flood hazard, vulnerability and risk in the Upper Brahmaputra River valley using stakeholders' knowledge and multicriteria evaluation (MCE). J Flood Risk Manage. 11:S700-S716.

Hishe S, Bewket W, Nyssen J, Lyimo J. 2020. Analysing past land use land cover change and CA-Markov-based future modelling in the Middle Suluh Valley, Northern Ethiopia. Geocarto Int. 35(3):225-255.

Jain SK, Agarwal PK, Singh VP. 2007. Brahmaputra and Barak Basin. In Hydrology and water resources of India. Dordrecht: Springer; p. 419-472. 
Khosravi K, Panahi M, Golkarian A, Keesstra SD, Saco PM, Bui DT, Lee S. 2020. Convolutional neural network approach for spatial prediction of flood hazard at national scale of Iran. J Hydrol. 591:125552.

Kontgis K, et al. "Global land use/land cover with Sentinel-2 and deep learning." IGARSS 2021-2021 IEEE Int Geoscience and Remote Sensing Symposium. IEEE, 2021.

706

707

708

709

710

711

712

713

714

715

716

Kumar R. 2016. Flood hazard assessment of 2014 floods in Sonawari sub-district of Bandipore district (Jammu \& Kashmir): An application of geoinformatics. Remote Sensing Applications: Society and Environ. 4:188-203.

Lyu HM, Sun WJ, Shen SL, Arulrajah A. 2018. Flood risk assessment in metro systems of mega-cities using a GIS-based modeling approach. Sci Total Environ. 626:1012-1025.

Majumder R, Bhunia GS, Patra P, Mandal AC, Ghosh D, Shit PK. 2019. Assessment of flood hotspot at a village level using GIS-based spatial statistical techniques. Arab J Geosci. 12(13):1-12.

Mishra K, Sinha R. 2020. Flood risk assessment in the Kosi megafan using multi-criteria decision analysis: A hydro-geomorphic approach. Geomorphology. 350:106861.

Pareta K. 2021. Multi-Criteria Analysis (MCA) for Identification of Vulnerable Areas Along Brahmaputra River in Assam and Their Field Assessment. J of Environ Protection and Sustainable Development. 7(2):15-29.

Pathak S, Liu M, Jato-Espino D, Zevenbergen C. 2020. Social, economic and environmental assessment of urban sub-catchment flood risks using a multi-criteria approach: A case study in Mumbai City, India. J Hydrol. 591:125216.

Pathan SA, Sil BS. 2020. Prioritization of soil erosion prone areas in upper Brahmaputra River Basin up to Majuli River Island. Geocarto Int. 1-19. 
Pourali SH, Arrowsmith C, Chrisman N, Matkan AA, Mitchell D. 2016. Topography wetness

725

726

727

728

729

730

731

732

733

734

735

736

737

738

739

740

741

742

743

744

745

746

747 index application in flood-risk-based land use planning. Appl Spatial Analysis and Policy. 9(1):39-54.

Rashetnia S, Jahanbani H. 2021. Flood vulnerability assessment using a fuzzy rule-based index in Melbourne, Australia. Sustainable Water Resources Manage. 7(2):1-13.

Rong Y, Zhang T, Zheng Y, Hu C, Peng L, Feng P. 2020. Three-dimensional urban flood inundation simulation based on digital aerial photogrammetry. J Hydrol. 584:124308.

Saaty TL. 2000. Fundamentals of decision making and priority theory with the analytic hierarchy process (6). RWS publications.

Saaty TL. 2008. Decision making with the analytic hierarchy process. Int J Services Sci. $1(1): 83-98$.

Sadeghi-Pouya A, Nouri J, Mansouri N, Kia-Lashaki A. 2017. An indexing approach to assess flood vulnerability in the western coastal cities of Mazandaran, Iran. Int J Disaster Risk Reduct. 22:304-316.

Sarkar D, Mondal P. 2020. Flood vulnerability mapping using frequency ratio (FR) model: a case study on Kulik river basin, Indo-Bangladesh Barind region. Appl Water Sci. 10(1):113.

Sarmah T, Das S, Narendr A, Aithal BH. 2020. Assessing human vulnerability to urban flood hazard using the analytic hierarchy process and geographic information system. Int $\mathrm{J}$ Disaster Risk Reduct. 50:101659.

Shahiri Tabarestani E, Afzalimehr H. 2021. A comparative assessment of multi-criteria decision analysis for flood susceptibility modelling. Geocarto Int. 1-24.

Sharma TPP, Zhang J, Koju UA, Zhang S, Bai Y, Suwal MK. 2019. Review of flood disaster studies in Nepal: A remote sensing perspective. Int J Disaster Risk Reduct. 34:18-27. 
748 Shivaprasad Sharma SV, Roy PS, Chakravarthi V, Srinivasa Rao G. 2018. Flood risk 749 assessment using multi-criteria analysis: a case study from Kopili River Basin, Assam, $750 \quad$ India. Geomat Nat Hazards Risk. 9(1):79-93.

751

752

753

754

755

756

757

758

759

760

761

762

763

764

765

766

767

768

769

Singh G, Rambabu VV, Chandra S. 1981. Soil loss prediction research in India. Bulletin of Central Soil and Water Conservation Research and Training Institute, T12/D9, Dehradun

Souissi D, Zouhri L, Hammami S, Msaddek MH, Zghibi A, Dlala M, 2020. GIS-based MCDM-AHP modeling for flood susceptibility mapping of arid areas, southeastern Tunisia. Geocarto Int. 35(9):991-1017.

Subrahmanyam VP. 1988. Hazards of floods and droughts in India. In Natural and man-made hazards. Dordrecht: Springer; p. 337-356.

Toosi AS, Calbimonte GH, Nouri H, Alaghmand S. 2019. River basin-scale flood hazard assessment using a modified multi-criteria decision analysis approach: A case study. $\mathbf{J}$ Hydrol. 574:660-671.

USDA. 2004. Estimation of direct runoff from storm rainfall. National Engineering Hand- book p. 79.

Vignesh KS, Anandakumar I, Ranjan R, Borah D. 2021. Flood vulnerability assessment using an integrated approach of multi-criteria decision-making model and geospatial techniques. Model Earth Syst Environ. 7(2):767-781.

Vojtek M, Vojteková J. 2019. Flood susceptibility mapping on a national scale in Slovakia using the analytical hierarchy process. Water. 11(2):364.

Wang X, Xie, H. 2018. A review on applications of remote sensing and geographic information systems (GIS) in water resources and flood risk management. Water. 10(5):608. 
775 Table 1. LULC classification and accuracy assessment

\begin{tabular}{|c|c|c|c|c|c|c|c|c|}
\hline $\begin{array}{c}\text { LULC } \\
\text { CLASS }\end{array}$ & Water & $\begin{array}{c}\text { Natural } \\
\text { Vegetation }\end{array}$ & Agriculture & $\begin{array}{c}\text { Built- } \\
\text { up }\end{array}$ & $\begin{array}{c}\text { Bare } \\
\text { Land }\end{array}$ & $\begin{array}{c}\text { Total } \\
\text { User }\end{array}$ & $\begin{array}{c}\text { Uccuracy } \\
\text { Aco) }\end{array}$ & $\begin{array}{c}\text { Producer's } \\
\text { Accuracy } \\
(\%)\end{array}$ \\
\hline Water & 75 & 0 & 0 & 0 & 3 & 78 & 96.15 & 96.15 \\
\hline $\begin{array}{c}\text { Natural } \\
\text { Vegetation }\end{array}$ & 0 & 65 & 6 & 0 & 3 & 74 & 87.84 & 91.55 \\
\hline Agriculture & 0 & 6 & 60 & 4 & 3 & 73 & 82.19 & 88.24 \\
\hline Built-up & 0 & 0 & 1 & 67 & 2 & 70 & 95.71 & 91.78 \\
\hline Barren Land & 3 & 0 & 1 & 2 & 72 & 78 & 92.31 & 86.75 \\
\hline $\begin{array}{c}\text { Total } \\
\text { Producer }\end{array}$ & 78 & 71 & 68 & 73 & 83 & 373 & & \\
\hline
\end{tabular}

776

777 Table 2. The scale of preference (Saaty 2008)

\begin{tabular}{|l|l|}
\hline Degree of preference & Scales \\
\hline Extremely & 9 \\
\hline Very strongly to extremely & 8 \\
\hline Very strongly & 7 \\
\hline Strongly to very strongly & 6 \\
\hline Strongly & 5 \\
\hline Moderately to strongly & 4 \\
\hline Moderately & 3 \\
\hline Equally to moderately & 2 \\
\hline Equally & 1 \\
\hline
\end{tabular}


Table 3. Value of Random Index (Saaty 2000)

\begin{tabular}{|l|l|l|l|l|l|l|l|l|l|l|l|l|l|}
\hline $\mathbf{n}$ & 3 & 4 & 5 & 6 & 7 & 8 & 9 & 10 & 11 & 12 & 13 & 14 & 15 \\
\hline RI & 0.52 & 0.89 & 1.11 & 1.25 & 1.35 & 1.40 & 1.45 & 1.49 & 1.51 & 1.54 & 1.56 & 1.57 & 1.58 \\
\hline
\end{tabular}

780

781 Table 4. Flood hazard indicators

\begin{tabular}{|c|c|c|c|c|c|}
\hline Indicator & $\mathrm{W}_{\text {ind }}$ & Subclass & $\begin{array}{l}\% \text { of } \\
\text { area }\end{array}$ & $\begin{array}{c}\text { Effective } \\
\text { weight } \\
\text { (EF) }\end{array}$ & $\begin{array}{c}\text { Normalized } \\
\text { EF }\end{array}$ \\
\hline \multirow{5}{*}{$\begin{array}{c}\text { Elevation } \\
\text { (ELV) }\end{array}$} & \multirow[t]{5}{*}{0.10} & $5-135$ & 73.69 & 5 & 0.33 \\
\hline & & $135.01-326$ & 14.37 & 4 & 0.27 \\
\hline & & $326.01-600$ & 6.11 & 3 & 0.20 \\
\hline & & $600.01-960$ & 4.62 & 2 & 0.13 \\
\hline & & $960.01-1964$ & 1.20 & 1 & 0.07 \\
\hline \multirow{5}{*}{$\begin{array}{l}\text { Slope } \\
\text { (Sl) }\end{array}$} & \multirow[t]{5}{*}{0.14} & $0-3.07$ & 48.83 & 5 & 0.33 \\
\hline & & $3.08-8.38$ & 30.14 & 4 & 0.27 \\
\hline & & $8.39-15.92$ & 12.46 & 3 & 0.20 \\
\hline & & $15.93-26.25$ & 6.21 & 2 & 0.13 \\
\hline & & $26.26-71.21$ & 2.35 & 1 & 0.07 \\
\hline \multirow{5}{*}{$\begin{array}{l}\text { Drainage Density } \\
\text { (Dd) }\end{array}$} & \multirow[t]{5}{*}{0.09} & $0-0.26$ & 30.28 & 1 & 0.07 \\
\hline & & $0.27-0.52$ & 29.93 & 2 & 0.13 \\
\hline & & $0.53-0.79$ & 23.32 & 3 & 0.20 \\
\hline & & $0.80-1.05$ & 14.47 & 4 & 0.27 \\
\hline & & $1.06-1.31$ & 2.00 & 5 & 0.33 \\
\hline \multirow{5}{*}{$\begin{array}{l}\text { Proximity to the river } \\
\text { (Dr) }\end{array}$} & \multirow[t]{5}{*}{0.10} & $0-500$ & 9.65 & 5 & 0.33 \\
\hline & & $501-1000$ & 8.73 & 4 & 0.27 \\
\hline & & $1001-2000$ & 15.44 & 3 & 0.20 \\
\hline & & $2001-4000$ & 24.68 & 2 & 0.13 \\
\hline & & $>4000$ & 41.49 & 1 & 0.07 \\
\hline \multirow{5}{*}{$\begin{array}{c}\text { Proximity to } \\
\text { embankment breach } \\
\text { locations (De) }\end{array}$} & \multirow[t]{5}{*}{0.05} & $0-500$ & 0.09 & 5 & 0.33 \\
\hline & & $501-1000$ & 0.27 & 4 & 0.27 \\
\hline & & $1001-2000$ & 1.04 & 3 & 0.20 \\
\hline & & $2001-4000$ & 3.74 & 2 & 0.13 \\
\hline & & $>4000$ & 94.86 & 1 & 0.07 \\
\hline \multirow[t]{5}{*}{ Soil texture $(\mathrm{St})$} & \multirow[t]{5}{*}{0.06} & Sandy clay loam & 52.54 & 5 & 0.33 \\
\hline & & Clay & 3.72 & 4 & 0.27 \\
\hline & & Sandy Loam & 4.86 & 3 & 0.20 \\
\hline & & Clay Loam & 6.01 & 2 & 0.13 \\
\hline & & Loam & 32.87 & 1 & 0.07 \\
\hline \multirow[t]{4}{*}{ Geology (Geo) } & \multirow[t]{4}{*}{0.02} & Metamorphic & 0.60 & 2 & 0.20 \\
\hline & & Paleozoic & 1.17 & 1 & 0.10 \\
\hline & & Precambrian & 12.85 & 2 & 0.20 \\
\hline & & Sedimentary & 85.38 & 5 & 0.50 \\
\hline
\end{tabular}




\begin{tabular}{|c|c|c|c|c|c|}
\hline \multirow[t]{5}{*}{ Geomorphology (Gm) } & \multirow[t]{5}{*}{0.03} & Alluvial plain & 43.74 & 5 & 0.31 \\
\hline & & Denudational hill & 1.53 & 2 & 0.13 \\
\hline & & Flood plain & 25.75 & 5 & 0.31 \\
\hline & & Pediplain & 5.89 & 3 & 0.19 \\
\hline & & Structural hill & 24.89 & 1 & 0.06 \\
\hline \multirow{3}{*}{$\begin{array}{l}\text { Topographic wetness } \\
\text { index (TWI) }\end{array}$} & \multirow[t]{3}{*}{0.05} & $2.35-8.06$ & 65.30 & 2 & 0.20 \\
\hline & & $8.07-11.83$ & 24.55 & 3 & 0.30 \\
\hline & & $11.84-28.33$ & 10.14 & 5 & 0.50 \\
\hline \multirow{5}{*}{$\begin{array}{l}\text { Rainfall intensity } \\
\text { (MFI) }\end{array}$} & \multirow[t]{5}{*}{0.19} & $148.45-254.22$ & 28.68 & 1 & 0.07 \\
\hline & & $254.23-359.98$ & 47.20 & 2 & 0.13 \\
\hline & & $359.99-465.75$ & 14.89 & 3 & 0.20 \\
\hline & & $465.76-571.51$ & 6.42 & 4 & 0.27 \\
\hline & & $571.52-677.28$ & 2.81 & 5 & 0.33 \\
\hline \multirow{5}{*}{$\begin{array}{l}\text { Rainfall Erosivity } \\
\text { Factor (REF) }\end{array}$} & \multirow[t]{5}{*}{0.03} & $419.02-639.71$ & 23.64 & 1 & 0.07 \\
\hline & & $639.72-786.84$ & 29.56 & 2 & 0.13 \\
\hline & & $786.85-941.32$ & 25.47 & 3 & 0.20 \\
\hline & & $941.33-1114.20$ & 14.39 & 4 & 0.27 \\
\hline & & $1114.21-1356.96$ & 6.93 & 5 & 0.33 \\
\hline \multirow{5}{*}{$\begin{array}{l}\text { Runoff coefficient } \\
\text { (RC) }\end{array}$} & \multirow[t]{5}{*}{0.12} & $0-0.04$ & 30.87 & 1 & 0.07 \\
\hline & & $0.05-0.08$ & 29.00 & 2 & 0.13 \\
\hline & & $0.09-0.13$ & 26.63 & 3 & 0.20 \\
\hline & & $0.14-0.20$ & 10.09 & 4 & 0.27 \\
\hline & & $0.21-30$ & 3.40 & 5 & 0.33 \\
\hline
\end{tabular}

Table 5. Flood vulnerability indicators

\begin{tabular}{|c|c|c|c|c|c|}
\hline Indicator & $\mathrm{W}_{\text {ind }}$ & Sub class & $\begin{array}{l}\% \text { of } \\
\text { area }\end{array}$ & $\begin{array}{c}\text { Effective } \\
\text { weight } \\
\text { (EF) }\end{array}$ & $\begin{array}{c}\text { Normalized } \\
\text { EF }\end{array}$ \\
\hline \multirow{5}{*}{$\begin{array}{l}\text { Population density } \\
\text { (PD) }\end{array}$} & \multirow[t]{5}{*}{0.21} & $43.65-91.79$ & 19.54 & 1 & 0.07 \\
\hline & & $91.80-364.22$ & 27.27 & 2 & 0.13 \\
\hline & & $364.23-530.01$ & 31.53 & 3 & 0.20 \\
\hline & & $530.02-743.15$ & 20.65 & 4 & 0.27 \\
\hline & & $743.16-1574.76$ & 1.02 & 5 & 0.33 \\
\hline \multirow{5}{*}{$\begin{array}{c}\text { Vulnerable } \\
\text { population (VP) }\end{array}$} & \multirow[t]{5}{*}{0.19} & $59.23-65.34$ & 1.03 & 3 & 0.14 \\
\hline & & $65.35-69.34$ & 38.03 & 4 & 0.19 \\
\hline & & $69.35-70.44$ & 28.97 & 4 & 0.19 \\
\hline & & $70.45-71.19$ & 10.01 & 5 & 0.24 \\
\hline & & $71.20-73.48$ & 21.97 & 5 & 0.24 \\
\hline \multirow{5}{*}{$\begin{array}{l}\text { Employment rate } \\
\text { (Emp) }\end{array}$} & \multirow[t]{5}{*}{0.03} & $32.49-33.17$ & 6.91 & 5 & 0.33 \\
\hline & & $33.18-36.68$ & 22.68 & 4 & 0.27 \\
\hline & & $36.69-40.21$ & 33 & 3 & 0.20 \\
\hline & & $40.22-42.81$ & 26.06 & 2 & 0.13 \\
\hline & & $42.82-46.17$ & 11.34 & 1 & 0.07 \\
\hline \multirow[t]{2}{*}{ Literacy rate (LR) } & \multirow[t]{2}{*}{0.03} & $47.32-53.90$ & 9.99 & 5 & 0.33 \\
\hline & & $53.91-58.75$ & 32.56 & 4 & 0.27 \\
\hline
\end{tabular}




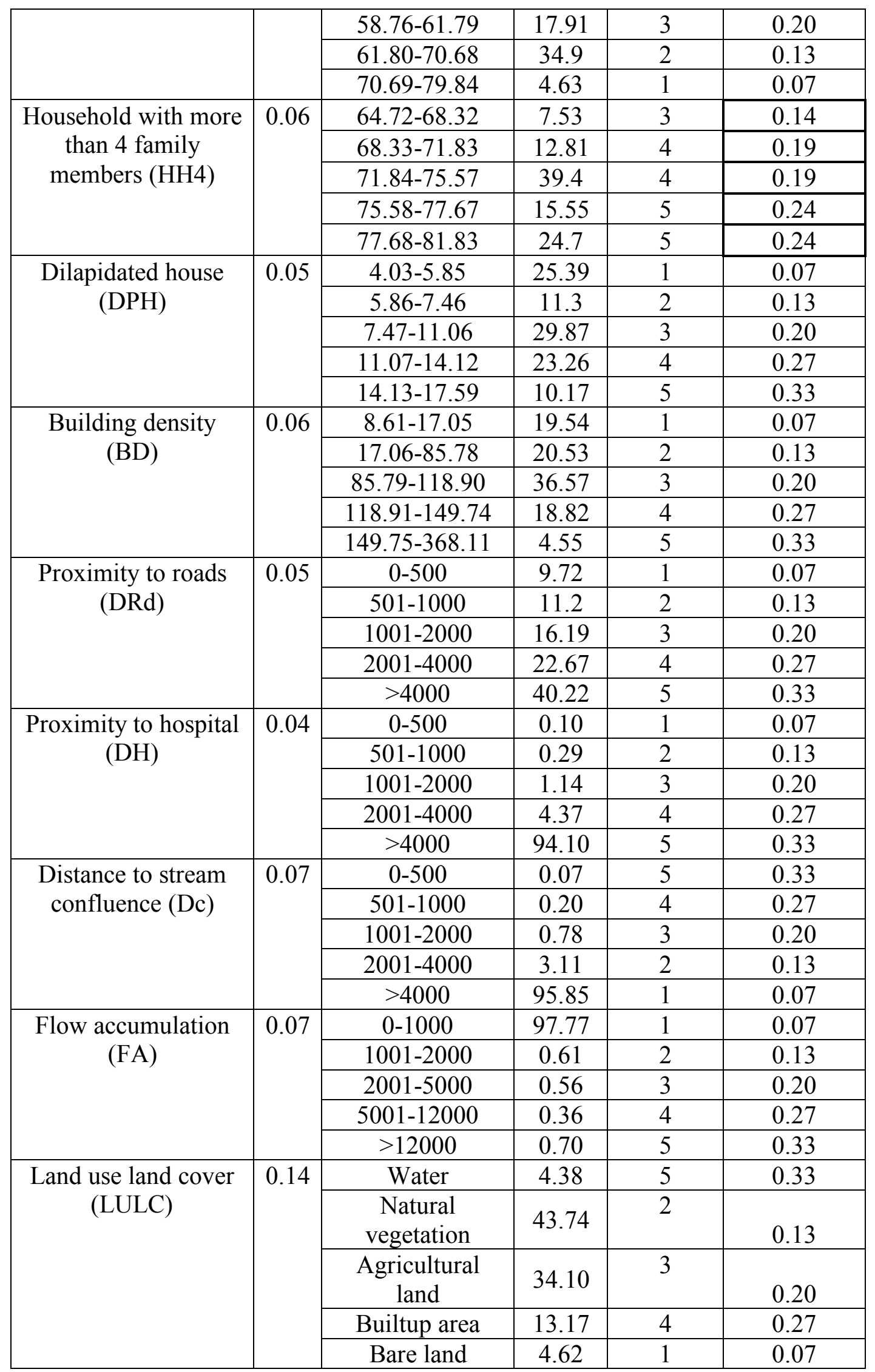


Table 6. Pair-wise comparison for flood hazard indicators

787

\begin{tabular}{|l|l|l|l|l|l|l|l|l|l|l|l|l|l|}
\hline Indicators & MFI & Sl & ELV & Dr & Dd & St & REF & TWI & De & Gm & RC & Geo & W $_{\text {ind }}$ \\
\hline MFI & 1 & 3 & 3 & 3 & 3 & 4 & 5 & 3 & 4 & 4 & 1 & 4 & 0.19 \\
\hline S1 & & 1 & 3 & 2 & 2 & 4 & 5 & 3 & 4 & 3 & 1 & 5 & 0.15 \\
\hline ELV & & & 1 & 2 & 1 & 3 & 4 & 3 & 3 & 3 & 0.33 & 5 & 0.10 \\
\hline Dr & & & & 1 & 2 & 3 & 4 & 3 & 2 & 3 & 1 & 4 & 0.10 \\
\hline Dd & & & & & 1 & 3 & 4 & 3 & 2 & 3 & 1 & 4 & 0.09 \\
\hline St & & & & & & 1 & 4 & 2 & 2 & 2 & 0.50 & 2 & 0.06 \\
\hline REF & & & & & & & 1 & 2 & 1 & 1 & 0.20 & 2 & 0.03 \\
\hline TWI & & & & & & & & 1 & 1 & 2 & 1 & 2 & 0.05 \\
\hline De & & & & & & & & & 1 & 3 & 0.33 & 4 & 0.05 \\
\hline Gm & & & & & & & & & & 1 & 0.33 & 3 & 0.03 \\
\hline RC & & & & & & & & & & & 1 & 4 & 0.12 \\
\hline Geo & & & & & & & & & & & & 1 & 0.02 \\
\hline
\end{tabular}

Table 7. Pair-wise comparison for flood vulnerability indicators

\begin{tabular}{|l|l|l|l|l|l|l|l|l|l|l|l|l|l|}
\hline Indicator & P & V & LUL & D & F & B & HH & DR & DP & D & L & Em & $\mathrm{W}_{\text {in }}$ \\
s & D & P & C & c & A & D & 4 & d & H & H & R & p & d \\
\hline PD & 1 & 1 & 4 & 4 & 4 & 3 & 3 & 4 & 4 & 5 & 4 & 4 & 0.21 \\
\hline VP & & 1 & 3 & 3 & 3 & 3 & 3 & 4 & 4 & 5 & 4 & 4 & 0.19 \\
\hline LULC & & & 1 & 3 & 4 & 3 & 3 & 3 & 3 & 4 & 4 & 3 & 0.14 \\
\hline Dc & & & & 1 & 1 & 2 & 2 & 2 & 2 & 1 & 2 & 2 & 0.07 \\
\hline FA & & & & & 1 & 1 & 1 & 2 & 2 & 3 & 2 & 2 & 0.07 \\
\hline BD & & & & & & 1 & 1 & 1 & 2 & 2 & 2 & 2 & 0.06 \\
\hline HH4 & & & & & & & 1 & 1 & 2 & 2 & 2 & 2 & 0.06 \\
\hline DRd & & & & & & & & 1 & 1 & 2 & 1 & 1 & 0.05 \\
\hline DPH & & & & & & & & & 1 & 2 & 2 & 2 & 0.05 \\
\hline DH & & & & & & & & & & 1 & 2 & 2 & 0.04 \\
\hline LR & & & & & & & & & & & 1 & 1 & 0.03 \\
\hline Emp & & & & & & & & & & & & 1 & 0.03 \\
\hline
\end{tabular}

789

790 Table 8. Confusion matrix for flood hazard

\begin{tabular}{|c|c|c|c|}
\hline \multirow[b]{2}{*}{ Observed } & \multicolumn{3}{|c|}{ Predicted } \\
\hline & Non-Flood & Flood & Total \\
\hline Non-Flood & $\mathrm{P}_{\text {TRUE }}$ & $\mathrm{N}_{\text {FALSE }}$ & Positive \\
\hline Flood & P FALSE & $\mathrm{N}_{\text {TRUE }}$ & Negative \\
\hline Non-Flood & 88878692 & 10153760 & 99032452 \\
\hline Flood & 5777206 & 67551350 & 73328556 \\
\hline
\end{tabular}



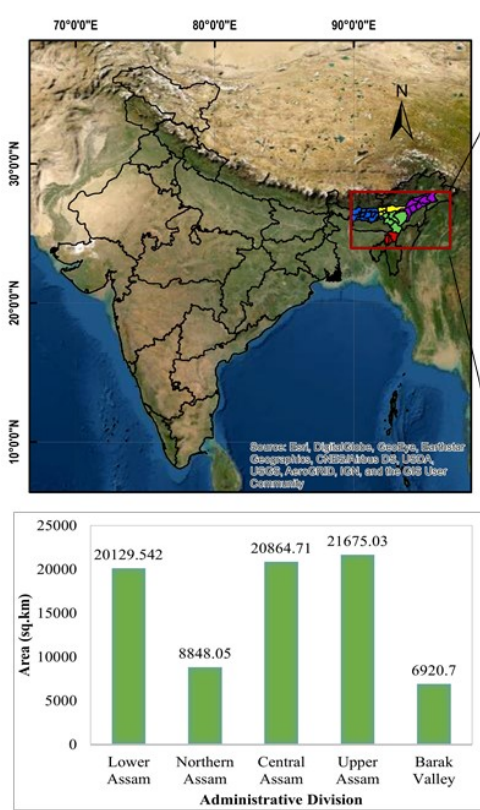

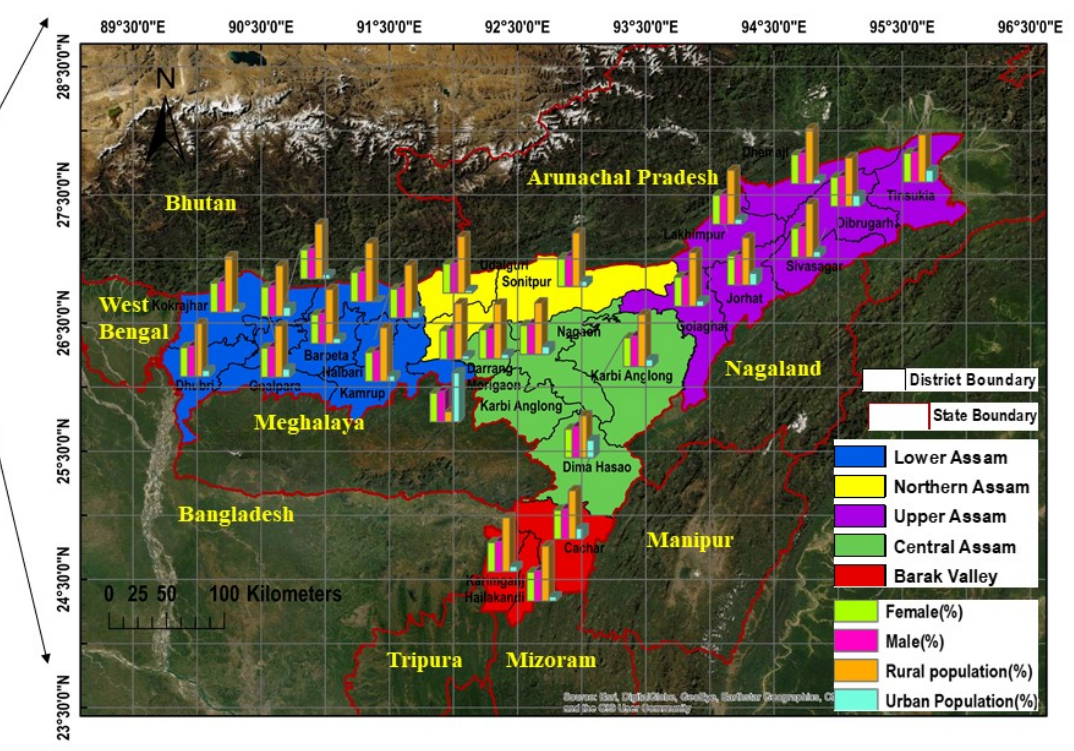

793

Figure 1. Map of the study area
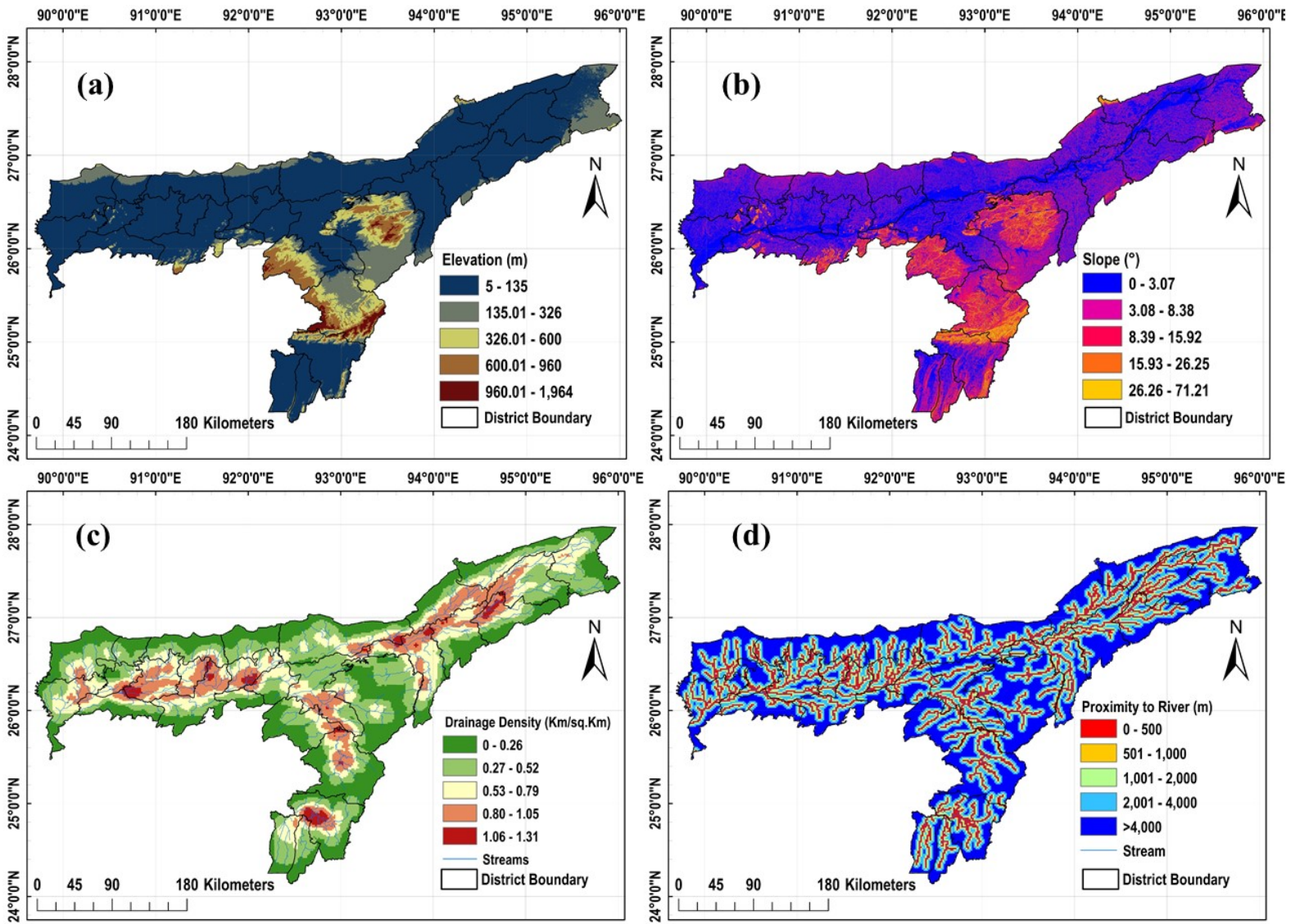

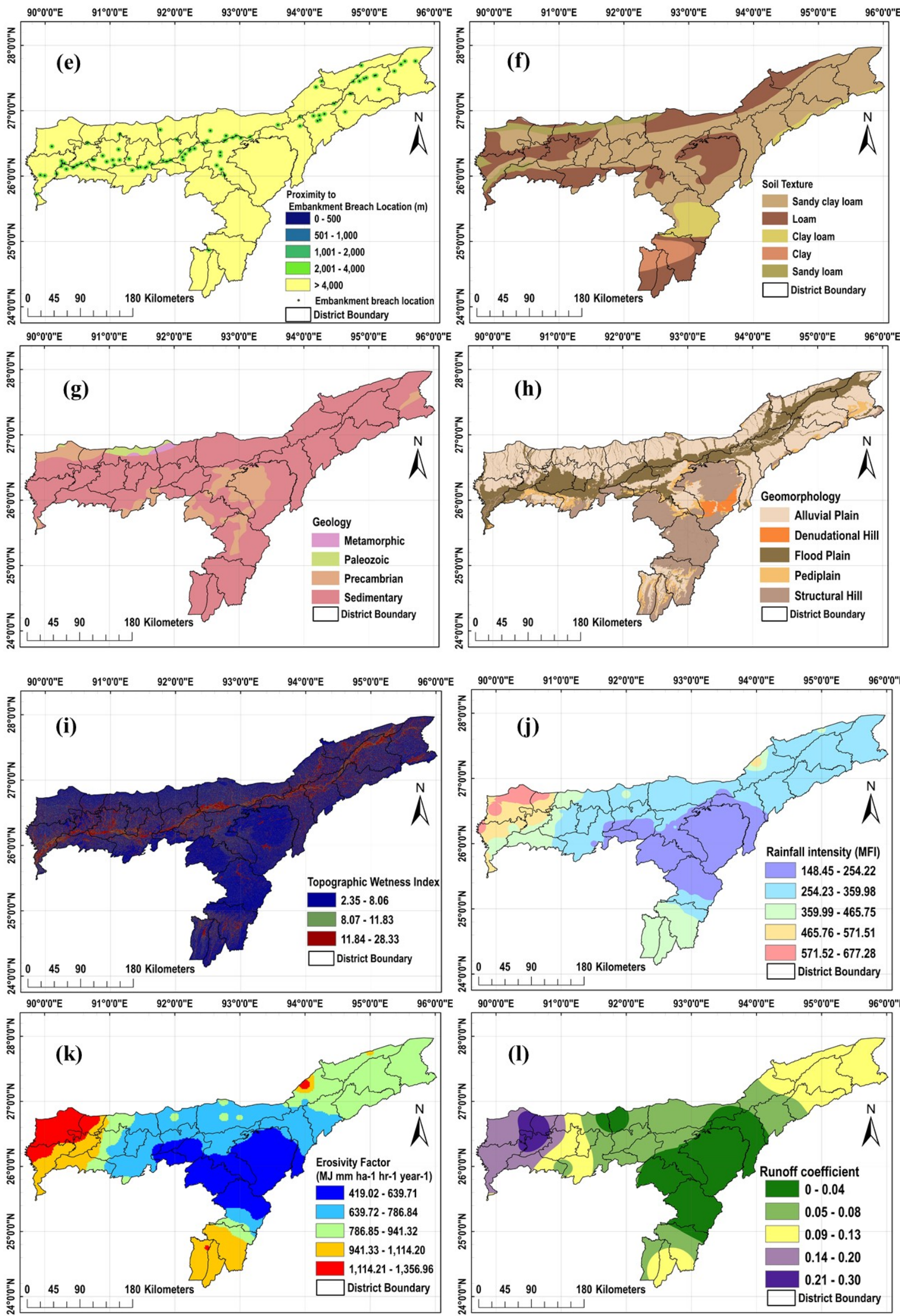
800 Figure 2. Flood hazard indicators (a) to (1) indicate elevation; slope; drainage density;

801 proximity to the river; proximity to embankment; soil texture; geology; geomorphology; TWI;

802 Rainfall intensity; erosivity factor; and runoff coefficient.

803
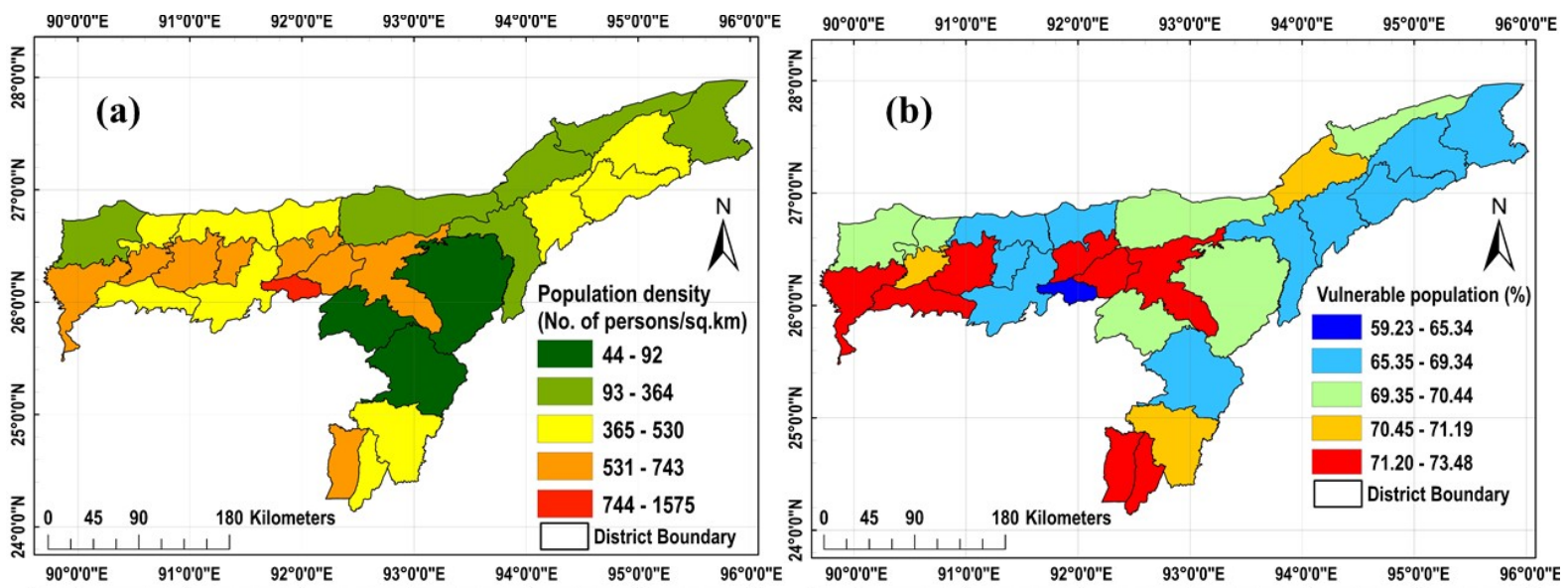

804
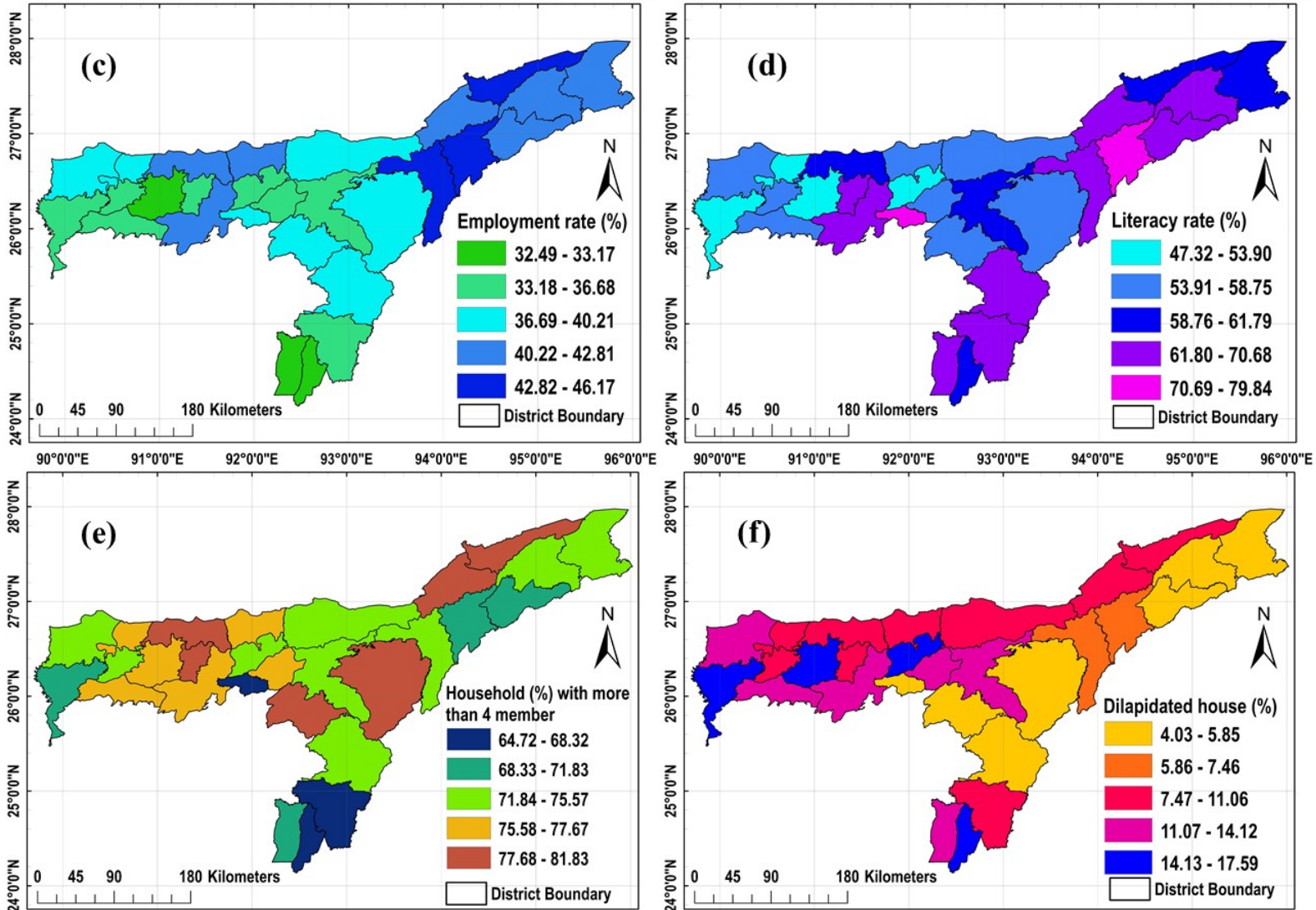

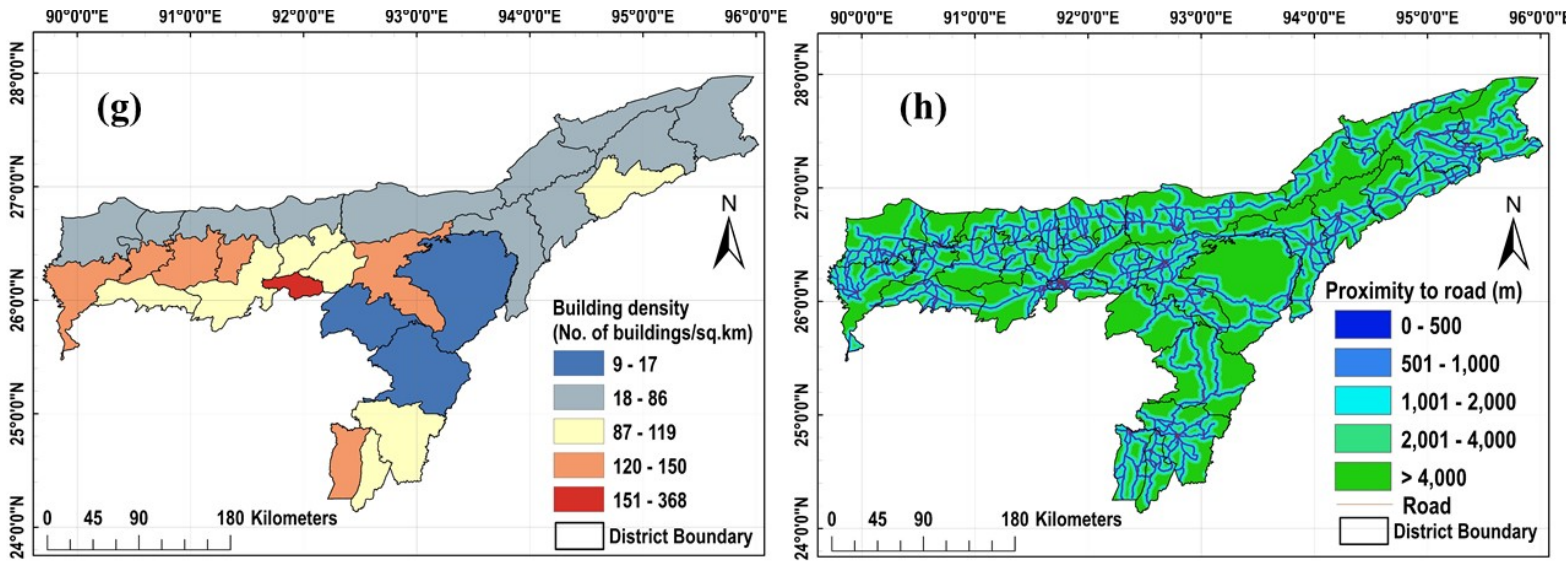

807
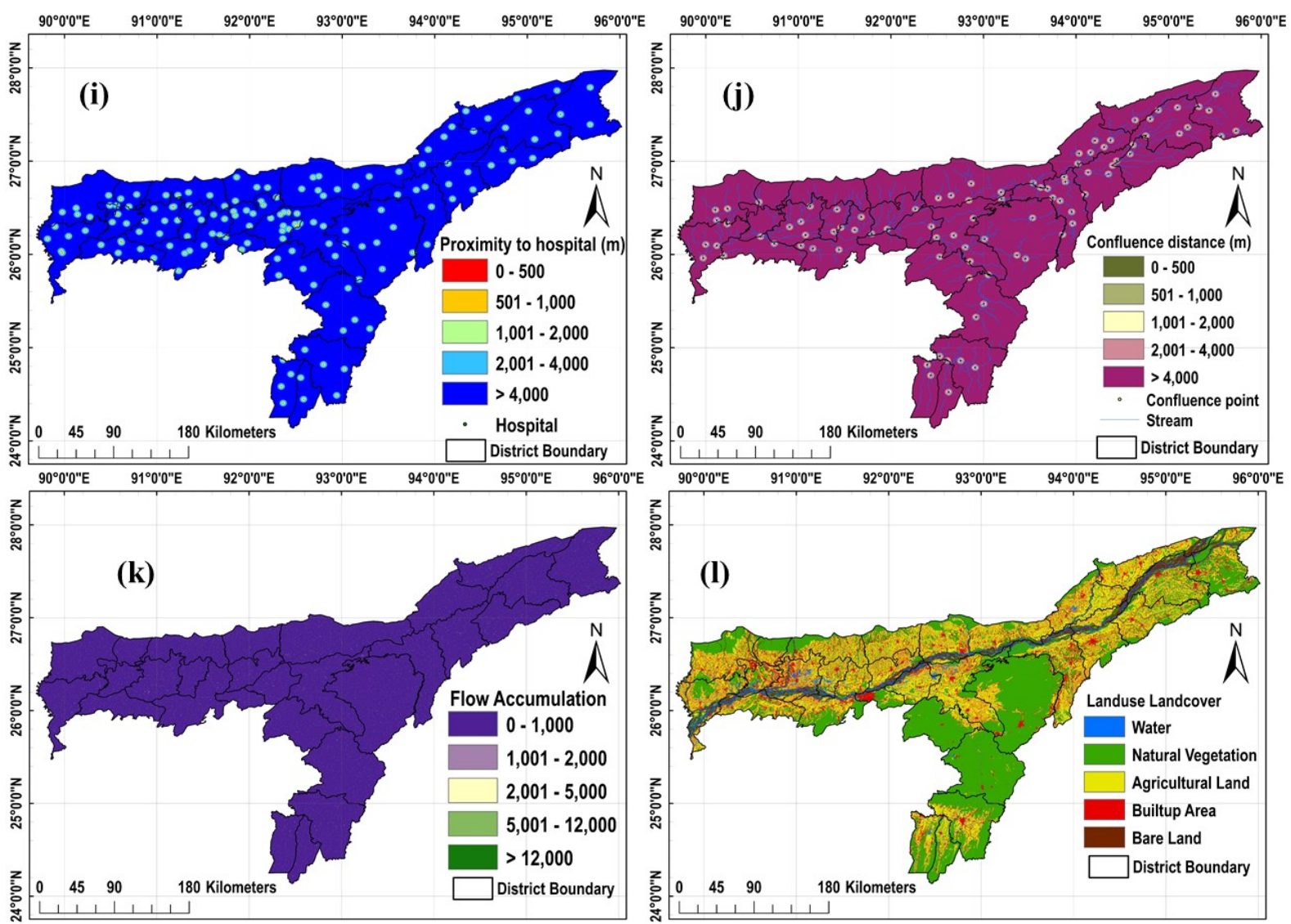

808

809 Figure 3. Flood vulnerability indicators (a) to (1) indicate population density; vulnerable

810 population; employment rate; literacy rate; a household with more than 4 members; dilapidated

811 house; building density; proximity to the road; proximity to the hospital; confluence distance;

812 flow accumulation; and LULC. 

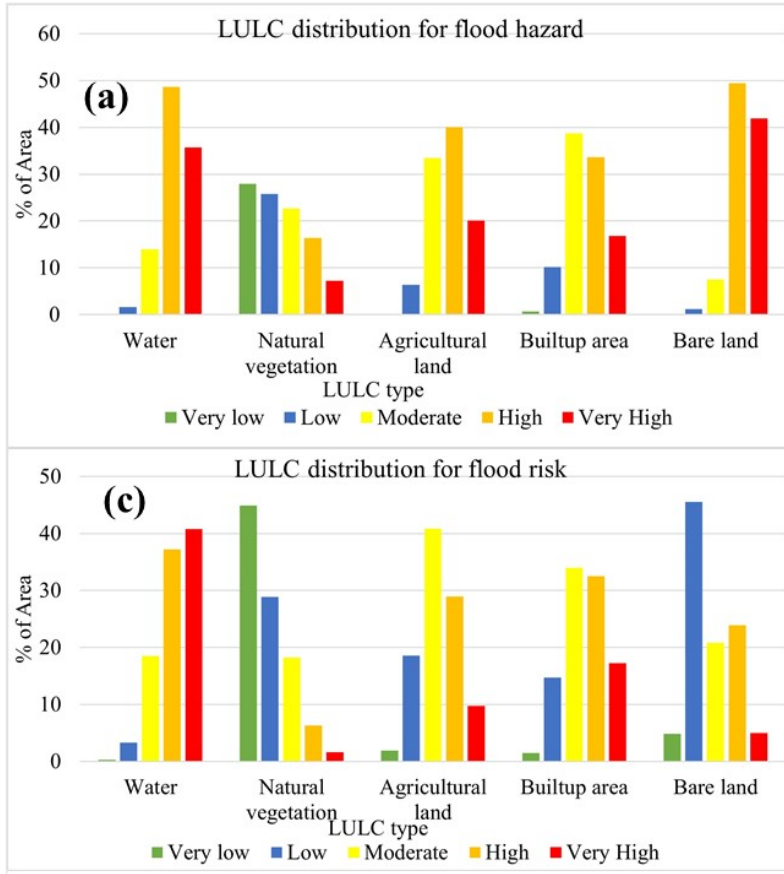

LULC distribution for flood vulnerability

(b)
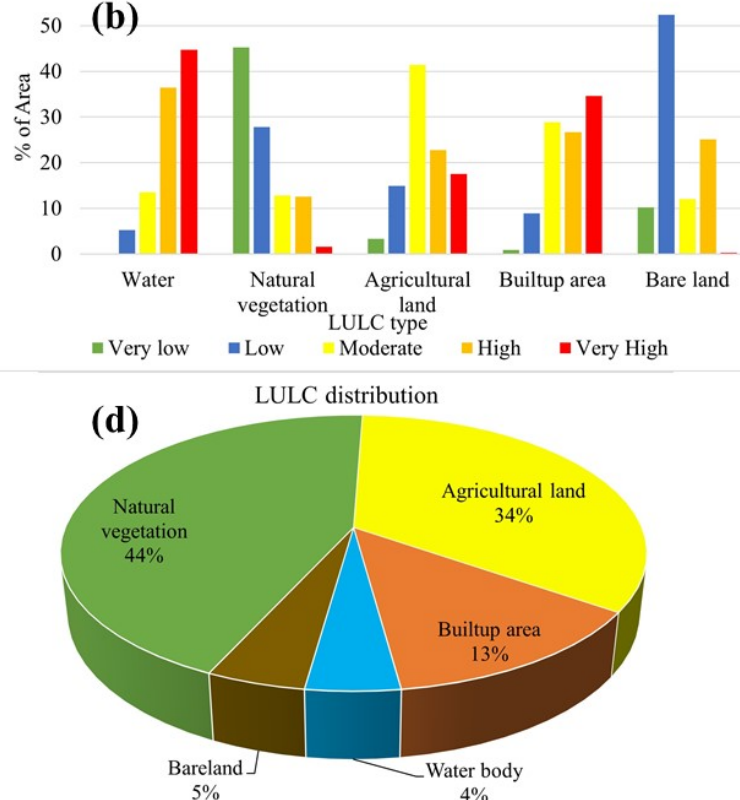

814 Figure 4. LULC area distribution for (a) Flood hazard; (b) Flood vulnerability; (c) Flood risk; 815 and (d) LULC distribution.
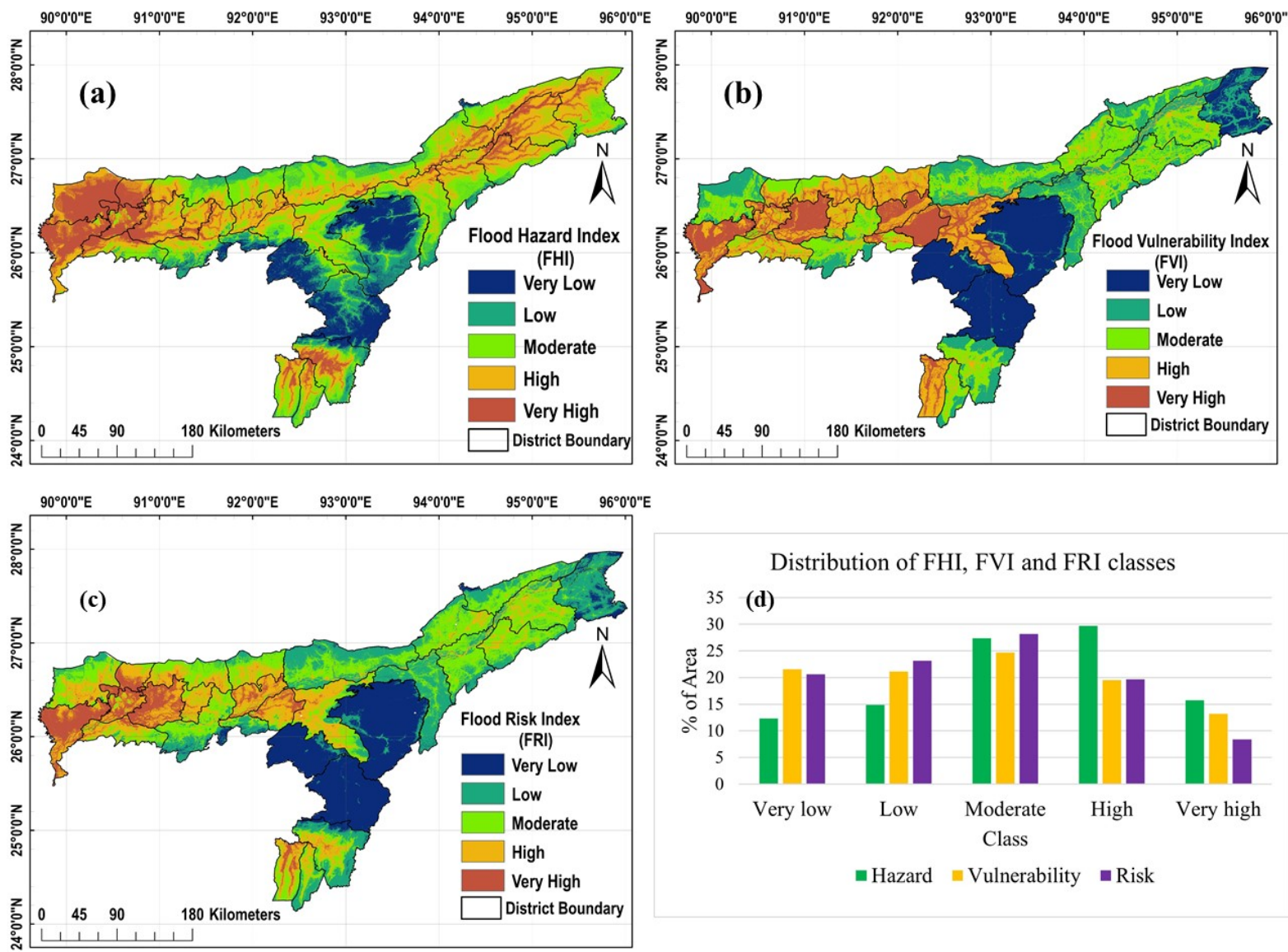

Distribution of FHI, FVI and FRI classes

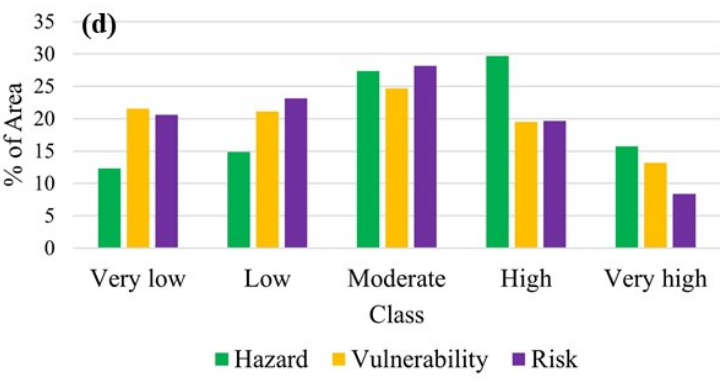


818 Figure 5. (a) Flood hazard index; (b) Flood vulnerability index; (c) Flood risk index; and (d)

819 Area-wise distribution of FHI, FVI, and FRI.
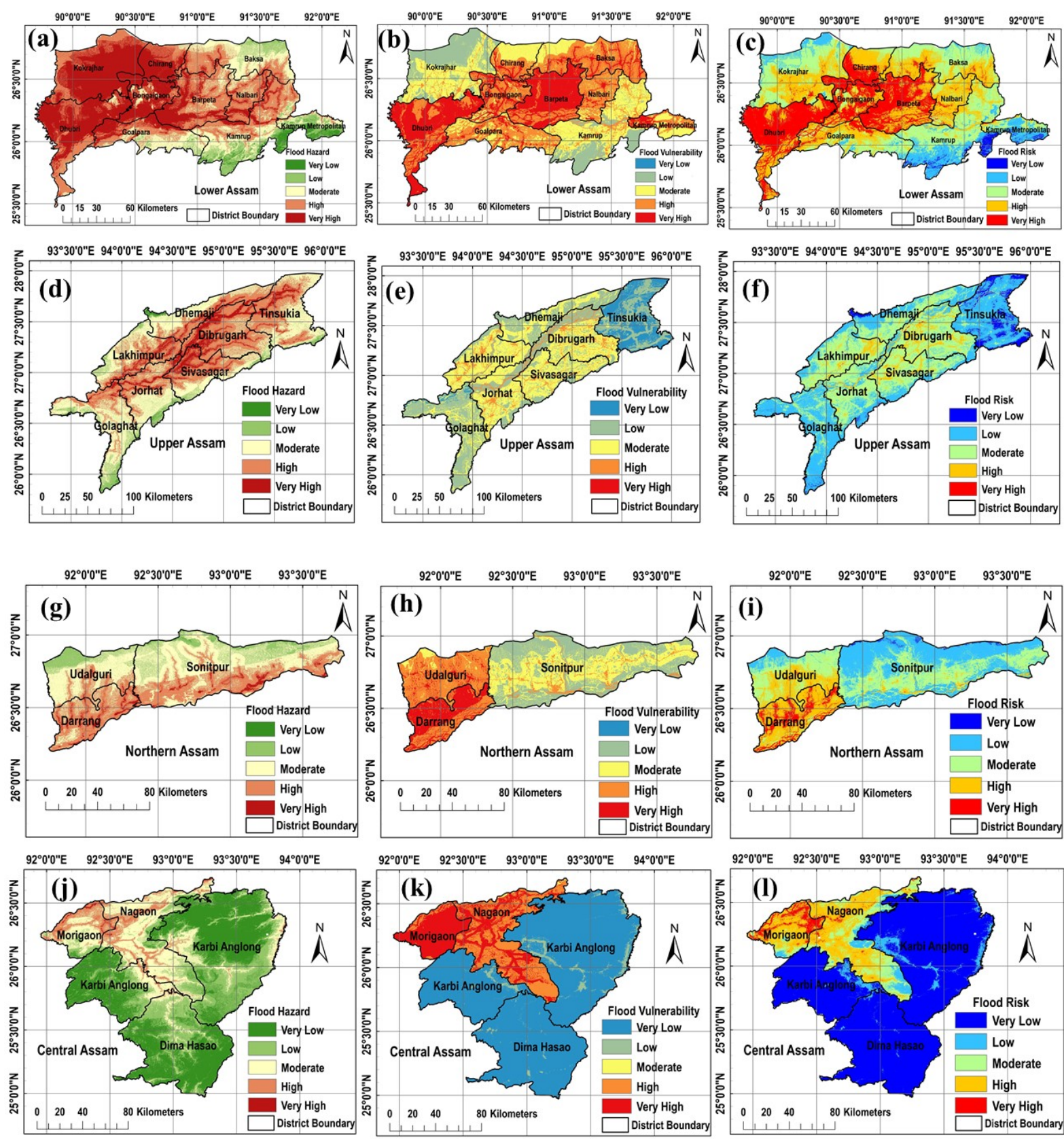


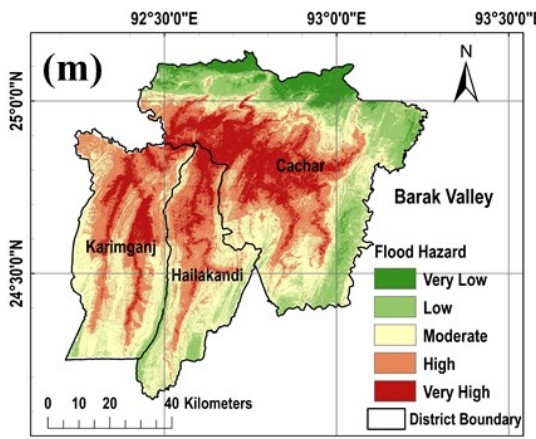

Flood hazard zonation at administrative level

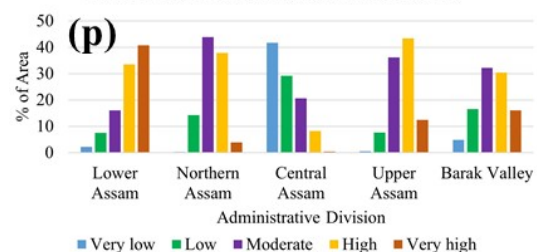

822

823 Figure 6. Flood profile of Assam at the administrative level (a) to (c) Lower Assam; (d) to (f)

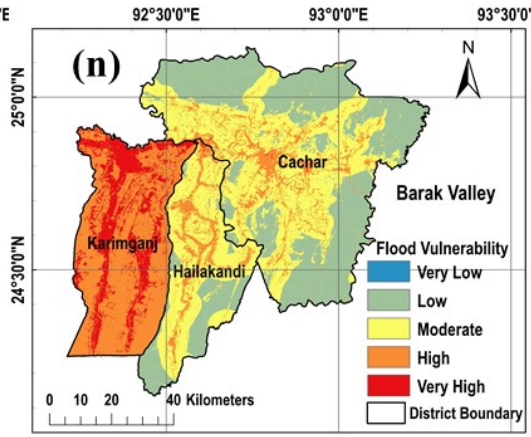

Flood vulnerability zonation at administrative level ${ }_{70}^{80}(\mathbf{q})$

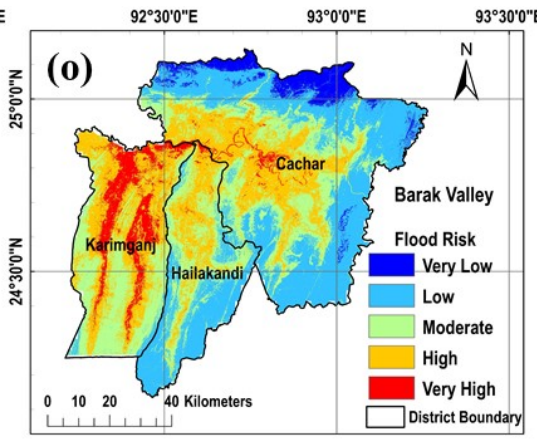

Flood risk zonation at administrative level ${ }_{70}^{80}(\mathbf{r})$

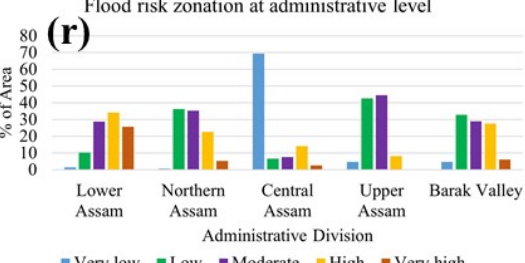

824 Upper Assam; (g) to (i) Northern Assam; (j) to (1) Central Assam; (m) to (o) Barak Valley; and (p) to (r) Area distribution of flood hazard, vulnerability, and risk. 